\title{
Key performance indicators disclosure in the context of the EU directive: when does stakeholder pressure matter?
}

\author{
Joanna Krasodomska
}

Department of Financial Accounting, Cracow University of Economics, Krakow, Poland, and

Ewelina Zarzycka

Department of Accounting, University of Lodz, Lodz, Poland

\begin{abstract}
Purpose - The paper aims to explore the effect of stakeholder pressure on the disclosure of key performance indicators (KPIs) and the patterns of this disclosure in large public interest entities (PIEs).

Design/methodology/approach - The study is based on the content analysis of the disclosures provided by 169 large (PIEs) operating in Poland in 2019. The data was hand-collected from the companies' non-financial statements. The research hypotheses were empirically tested with the use of linear regression.

Findings - The explanation for the disclosure of KPIs can be found in stakeholder theory, operationalized by stakeholder pressure linked to industry. In line with the expectations, businessrelated KPIs are disclosed by companies operating in industries with high pressure from investors, environment-related KPIs are presented by companies operating in environmentally sensitive industries and companies operating in industries with high pressure from employees disclose societyrelated KPIs. According to the results of the study, reporting on employee-related KPIs is accompanied by environmental and social KPI disclosures.

Originality/value - The study contributes to the literature on corporate non-financial disclosures as it provides new insights into non-financial KPI disclosures in a new and relatively unexplored institutional setting established by the Directive 2014/95/EU. While researchers recognize the stakeholders' environmental and social concerns, there is nevertheless a lack of understanding of their implications for KPIs in measuring social practice. The research fills that gap by addressing the specific impact of different stakeholder groups on the disclosure of KPIs.
\end{abstract}

Keywords Key performance indicators, Non-financial reporting, Directive 2014/95/EU

Paper type Research paper

(C) Joanna Krasodomska and Ewelina Zarzycka. Published by Emerald Publishing Limited. This article is published under the Creative Commons Attribution (CC BY 4.0) licence. Anyone may reproduce, distribute, translate and create derivative works of this article (for both commercial and non-commercial purposes), subject to full attribution to the original publication and authors. The full terms of this licence maybe seen at http://creativecommons.org/licences/by/ 4.0/legalcode

The authors wish to thank the participants of the 9th International Conference Financial Reporting and Auditing in Krakow, Poland for their helpful feedback, comments and suggestions. This work was supported by the National Science Centre, Poland under Grant number 2019/33/B/HS4/00998.

Received 4 May 2020

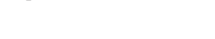


MEDAR

29,7

\section{Introduction}

Traditional financial statements include historical financial data relating to companies' financial positions and results of operations. Despite the obvious usefulness of such disclosures, they do not present the whole picture of the company's performance. Making money for shareholders is no longer perceived as the company's only goal (Gray et al., 2017), and concepts such as corporate social responsibility (CSR) or sustainable development have gained momentum as inescapable issues for business (Lisi, 2015). Companies face pressures from stakeholders to operate in line with these concepts and to disclose more information about how they perform in this regard (Welbeck, 2017). Therefore, they need to become more proactive, transparent and future-oriented in their measuring and reporting of CSR-related activities (Burnett and Hansen, 2008; Perego and Hartmann, 2009).

The rising importance of the CSR notion has led to significant institutional changes in the corporate reporting landscape. In 2018, large public interest entities (PIEs [1]) in the European Union (EU) ended the first reporting season under the new requirements of the Directive 2014/95/ EU. With the introduction of the Directive, non-financial disclosures were officially included within the scope of corporate reporting (EU, 2014b; Dumay et al, 2019; Andrades Peña and Jorge, 2019). As La Torre et al. (2018) argue, the Directive has two key objectives: one is to make nonfinancial information comparable across the $\mathrm{EU}$ and the other is to enhance corporate accountability through mandatory non-financial reporting. According to the new law, large PIEs, with an average of 500 employees or more, are required to prepare a non-financial statement containing information about their practices with regard to environmental matters, social and employee-related issues, respect for human rights and anti-corruption and bribery. In 2017, the European Commission (EC) adopted the non-binding guidelines on non-financial reporting to help companies to disclose non-financial information in a relevant, useful, consistent and more comparable manner (EC, 2017). Article 1 of the Directive states that the non-financial disclosures must include information on non-financial key performance indicators (KPIs) relevant to the particular business (EU, 2014b). As noted in the EC guidelines, "users of information tend to greatly appreciate quantitative information as it helps them measure progress, check consistency over time and draw comparisons" (EC, 2017, p. 13).

Given the fact that social and environmental impacts are difficult to express in monetary terms, KPIs provide an opportunity to capture them in the form of indicators that can be conveniently used by stakeholders. The lack of strict regulation or a list of the KPIs, which have to be disclosed, makes it possible for the companies to decide for themselves which KPIs to disclose and how to do it to make them transparent and relevant for the stakeholders. Parmenter (2015, p. 7) defines KPIs as "those indicators that focus on the aspects of organizational performance that are the most critical for the current and future success of the organization". KPIs are used to:

- monitor compliance with external regulations and standards;

- facilitate social decision-making by managers; and

- provide information about social and environmental activities and performance for stakeholders (Henri and Journeault, 2010).

KPIs, which complement narrative non-financial disclosures, allow the corporate nonfinancial performance to be presented quantitatively and more comparably. However, their selection and disclosure might pose significant challenges, especially for these PIEs, which have just started to provide non-financial information.

While there is a significant amount of research on firms' external CSR reporting practices in general, relatively little is known about the use of KPIs and how it is influenced by the 
corporate stakeholders (Givoly et al., 2019). Therefore, the aim of our study is to explore the effect of stakeholder pressure on the disclosure of KPIs and patterns of this disclosure in the researched companies. We use the managerial branch of stakeholder theory as the basis for this paper and the study because this theory provides an explanation of why companies engage in CSR and provide related non-financial disclosures (Ditlev-Simonsen and Wenstøp, 2013; Nielsen and Thomsen, 2007; Miles, 2019). It is also seen as an adequate framework for their evaluation (Snider et al., 2003). According to the stakeholder theory, the corporate decision to disclose particular KPIs should be primarily focused on the information needs of stakeholders. At the same time, the selection of the KPIs are influenced by the industry in which a company operates (Gamerschlag et al., 2011; Ho and Taylor, 2007; Pérez et al., 2015; Prado-Lorenzo et al., 2009). In our approach, we follow Fernandez-Feijoo et al. (2013), who created four categories of industries based on the pressure of four main groups of stakeholders (customers, employees, environment and investors) to study the relationship between these groups and KPI disclosures.

We have analysed the KPI disclosures of 169 large PIEs operating in Poland with the use of the binary disclosure index. This approach is often used in social science and shows whether an item is present or absent (Beattie et al., 2004). The index takes a value of " 1 " (the information is available) or " 0 " (the information is not available) (Raffournier, 2006; Michelon et al., 2014; Garanina and Dumay, 2017; Hummel et al., 2017; Beske et al., 2020). The data was hand-collected from the companies' non-financial statements published in 2019. Further, we use the linear regression analysis to test the research hypotheses. The study findings indicate that sample companies provide a variety of non-financial indicators. The research confirms the importance of employees and investors as pressure groups for disclosing the KPIs related to social matters and business operations, respectively. In line with our expectations, environment-related KPIs are disclosed by companies operating in environmentally sensitive industries (ESI), in which the stakeholders' awareness of the environmental issues is significant. Interestingly, there is a correlation between social, employee and environmental KPI disclosures. In other words, the companies that disclose KPIs related to environmental and social issues, intensely use the KPIs to report on employee matters.

This study provides new insights into non-financial KPI disclosures in a new and relatively unexplored institutional setting, thus contributing to the CSR literature (Lisi, 2018; Chang et al., 2014; Arvidsson, 2011; Nielsen et al., 2017). Despite the stakeholders' environmental and social concerns, there has been scant evidence as to when and how stakeholders' pressures matter for the non-financial KPI disclosures measuring their social practice (Thomson, 2007). Thus, our study widens the stakeholder's perspective by addressing the specific impact of different stakeholder groups on the disclosure of KPIs (Fernandez-Feijoo et al., 2013; Lisi, 2018). It may be interesting for the governmental agencies, national accounting associations, standard-setters and managers as an incentive to take a proactive approach to improve the quality of KPI disclosures provided by the large PIEs and develop a holistic system of CSR measurement aligned with the stakeholder's information needs.

More specifically, as regard the EU regulation environment, our study findings support the claim that there is a need to better align the practices of companies in the field of non-financial KPI reporting. The identified relations in the current corporate KPI disclosures allow us to state that they are not random and that the similarities between them are stakeholder-driven. What is more, we are able to state that environmental and social disclosures trigger employee disclosures. Therefore, all initiatives aimed at enhancing the quality of environmental and social disclosures within the EU should be supported. Given the fact, that the environmental 
MEDAR 29,7

disclosures, in particular related to climate change risk, are gaining special attention from the regulators and other institutions, their expected positive influence on other reporting would be beneficial for the whole reporting process. In our opinion, the EU should follow the path initiated in the EC's Guidelines on reporting climate-related information issued in 2019 (EC, 2019), which proposes a clear set of climate change-related KPIs that might be disclosed by all companies. As a next step, a similar set of guidelines could be proposed by the EC as regard corporate social disclosures.

The paper proceeds as follows. Section 2 presents the main guidelines concerning nonfinancial KPI disclosures. Section 3 offers a review of the relevant literature, defines the research gap and develops the research hypotheses. The empirical study design is presented in Section 4, with particular focus on the sample, data collection and methodology, as well as the variables used in the regression model. Subsequently, the research findings are discussed in Section 5. Finally, Section 6 offers concluding remarks, information on the study's limitations and an indication as to future research possibilities.

\section{Non-financial key performance indicators disclosure}

While presenting non-financial disclosures, including KPIs, companies may follow various reporting frameworks such as Global Reporting Initiative (GRI) Standards, ISO 26000 or UN Global Compact. The study of Bradley and Botchway (2018) highlights the discretionary nature of CSR reporting, revealing considerable variance in the KPIs disclosed. According to Arvidsson (2011), for the corporate-disclosure process regarding KPIs to function efficiently, action should be undertaken not only by management teams but also by policymakers and financial market regulators. The response to this is the EU initiative and the publication of the Directive 2014/95/EU, as well as EC guidelines. However, both documents provide only general instructions on the matter. In line with the comments obtained during the public consultations that preceded the publication of the guidelines by the $\mathrm{EC}$, the document identifies key principles as regard KPI disclosures, provides for flexibility of exercising judgment by companies and makes reference to other frameworks. The initial idea to include a comprehensive list of KPIs in the EC guidelines was less strongly supported by the respondents participating in the consultations. Especially companies and business organizations suggested that it would not be appropriate to include such a list. As a result, the EC guidelines are very flexible, and they stress that KPIs should reflect the specific circumstances in which the companies operate and be closely related to the metrics used for internal management and risk assessment processes. Therefore, there are KPIs that might be relevant for almost all companies, but there are others that will be suitable only for issues and circumstances of a given industry [2].

A company should disclose those KPIs which are "necessary to understand its development, performance, position and impact of its activity" (EC, 2017, p. 13), and these disclosures must take into consideration "the information needs of investors and other stakeholders" (EC, 2017, p. 13). KPIs should be material, and they need to provide a fair and balanced view to provide stakeholders with information that is relevant, transparent and useful.

As stressed by the EC guidelines, KPI disclosures should fulfill the information needs of stakeholders. According to the literature, the use of non-financial KPIs for a wide variety of decision-making and control purposes can act as an intervening variable among business motivations, perceived stakeholder pressures and top management's environmental commitment on the one hand and environmental and economic performance on the other (Lisi, 2015). Management's social commitment is positively associated with KPI use (Arvidsson, 2011; Lisi, 2015). However, it is also external pressures from such stakeholder groups as investors, customers, clients, employees that improve the quality and transparency of 
non-financial disclosures (Fernandez-Feijoo et al., 2013). According to Ditlev-Simonsen and Wenstøp (2013) owners are the main motivators for managers to pursue CSR and its disclosure, followed by customers, governments, employees and non-governmental organizations.

Research in CSR disclosures and KPIs has grown and has explored a variety of issues (for literature review see among others: Mura et al., 2018; Wood, 2010). Although the abovementioned studies have enabled the gaining of a much deeper understanding of both technical and behavioural aspects of corporate non-financial performance measurement, they represent a highly fragmented field, with different theoretical perspectives, conceptualizations of the measurement process and contributions to practice (Mura et al., 2018). Still little is known about the pressure of different stakeholder groups and their expectations towards the social performance of organizations and their KPI disclosures. What is more, there is not much evidence available to make it possible to understand the patterns of disclosure on non-financial KPIs in the organizations and the relationship among the disclosures of various KPIs.

\section{Theoretical underpinning, literature review and hypotheses development \\ 3.1 Stakeholder theory}

Different theoretical perspectives have been used to study the motives behind voluntary CSR disclosures, their usefulness and transparency. One of the most commonly used is the stakeholder theory. It was introduced to the literature by Freeman (1984, p. 46), who defines a stakeholder as "any group or individual who can affect or is affected by the achievement of the organization's objectives". Initially, companies were seen as having only one stakeholder: the owners whose main expectation was the maximization of the return on equity. According to the stakeholder theory, a firm has to take into account the needs of its various stakeholders and balance their divergent interests. This usually requires taking into consideration which stakeholders' pressure matters the most (Fassin, 2012; Miles, 2019).

Stakeholder theory and CSR concepts are related as stakeholder theorists often define corporate behaviour with respect to the stakeholders (Driver and Thompson, 2002). Therefore, the stakeholder theory is commonly used as an explanatory theory for the company's decision to provide voluntary disclosures. It is also useful in exploring the stakeholders' influence, focusing on their information needs and addressing how the companies should tailor their response (Miles, 2019). Companies are called to disclose nonfinancial information to satisfy the demands and needs of several groups of stakeholders (Da Silva and Aibar-Guzmán, 2010). CSR reporting is even seen as a part of the dialogue between the company and its stakeholders (Gray et al., 1995, p. 53), and the inclusion of nonfinancial issues into corporate disclosure strategies beyond what is required by law can be viewed as a means to improve a company's alignment with the growing concerns and expectations of its stakeholders (Lisi, 2018).

Theorists identify two branches of stakeholder theory, normative and managerial (Gray et al., 1995). The normative stakeholder theory follows the idea that the company should consider all stakeholders' expectations. The managerial branch is closely aligned with the concept of stakeholder management. According to the managerial stakeholder theory, stakeholders can put pressure on the company to fulfill their expectations and management is persuaded to address the needs of the most influential groups. The managerial approach is used to describe how the company identifies stakeholders, manages relationships with them and follows their views (including sustainability concerns) in the decision-making processes (including these related to accounting and reporting) (Kaur and Lodhia, 2018). Corporate voluntary reporting is assumed to be driven by powerful stakeholders, which 
MEDAR 29,7

means that these stakeholders' information needs are most likely to be echoed in the disclosures provided (Farneti et al., 2019).

In this paper, the authors follow Kent and Zunker (2015) and the managerial branch of stakeholder theory as a theoretical lens is used. As indicated above, this theory allows researchers to identify the most critical stakeholders associated with particular nonfinancial disclosures rather than focus on stakeholders in the general range. As Kent and Zunker (2015) illustrate, it is expected that companies whose employees are powerful stakeholders will provide disclosures on employee-related information, while ecologists' groups are more likely to be powerful stakeholders for environment-related disclosures (Kent and Chan, 2009). For the companies operating in the financial sector, pressures from the shareholders and creditors are likely to be reflected in the extended financial reporting disclosures (Healy and Palepu, 2001; Fernandez-Feijoo et al., 2013).

In this study, the focus is on a particular type of non-financial disclosures, namely, KPIs. As Lisi (2018) argues, perceived pressures from stakeholder groups to disclose CSR information in the form of KPIs represent a strong incentive for corporate managers to integrate social and environmental criteria into the companies' performance measurement systems. Corporate non-financial reporting should reflect more extensive use of KPIs for decision-making and control purposes to improve their alignment to stakeholder pressure regarding the company's CSR priorities (Lisi, 2018; Arvidsson, 2011).

\subsection{Related research and hypotheses development}

KPIs and their use by companies are the topics of accounting research which is undertaken mostly in the context of economic motivations and impact on the corporate performance (Lisi, 2018; Chang et al., 2014), top management's environmental and social commitment and use of KPI for internal purposes (Lisi, 2018; Arvidsson, 2011; Nielsen et al., 2017), differences in corporate approaches to KPI disclosure (Bradley and Botchway, 2018) and the need for more regulation in this regard (Arvidsson, 2011). Companies disclose industry-specific KPIs to inform the stakeholders about the critical aspects of their performance (Givoly et al., 2019). As regard the influence of stakeholder pressure on the use of KPIs by companies, the literature does not provide much evidence for this and the findings of the studies conducted to date seem to deliver mixed results. According to Fernandez-Feijoo et al. (2013), the pressure of some groups of stakeholders (customers, clients, employees and environment) improves the transparency of the corporate disclosure. However, this study does not focus on KPI disclosures specifically. At the same time, Lisi (2018) does not provide evidence that perceived stakeholder pressure is a significant determinant of KPI use.

Previous research found a relationship between industry and CSR reporting (Gamerschlag et al., 2011; Ho and Taylor, 2007; Pérez et al., 2015; Prado-Lorenzo et al., 2009). The reason for this diversification is associated with the fact that industries are subject to specific and localized pressures from different stakeholders (Adams et al., 1998; Pérez et al., 2015; Fernandez-Feijoo et al., 2013). Therefore, in line with this assumption, we expect to identify a relationship between the stakeholders' influence and KPI disclosures. This stakeholder pressure, as is believed by the authors of this paper, is related to the industry in which the company operates.

Investors are seen as important users of financial and non-financial information provided by the companies (De Villiers, 2018). Mohamed et al. (2019) study findings show that some voluntary disclosures provided in the management report are more useful than mandatory disclosures. According to the Big 4 publications (PriceWaterhouseCoopers, 2007; Deloitte, 2012; Ernst and Young, 2015; KPMG, 2016) investors find voluntary disclosures of industryspecific KPIs significant for decision-making. Not only investors but also financial analysts 
increasingly follow and forecast the KPIs used by managers to make informed investment decisions (Givoly et al., 2019; Coram et al., 2011). KPIs which refer to business operations and a concern such issues as products, sales or customer satisfaction, seem to be especially useful as they have an understandable impact on the general corporate performance. Curtis et al. (2014) show that KPIs such as growth in same-store sales, the number of stores and new stores opened are convenient in predicting sales. Wu's (2012) study allowed for the identification of customer satisfaction, sales performance and customer retention rate as the most essential KPIs in the banking industry.

KPIs which relate to business operations might also be relevant for the second important group of corporate stakeholders, namely, customers. Customers also need sustainability disclosures (Bradford et al., 2017; De Villiers, 2018). According to the Ditlev-Simonsen and Wenstøp (2013) study, customers are the second important motivator (after owners), for managers to pursue CSR, but according to the respondents participating in the study, they ought to be the first. The companies' response to customer pressure is seen in terms of their ability to provide better products and services of the right quality and price. Providing information to customers on issues such as safety during the use of products or an ethical marketing policy aims to fulfil their expectations towards the corporate CSR practice (Mishra and Suar, 2010). It is expected that the companies operating in the industries where investors and customers can more effectively apply pressure, more relevant businessoriented KPIs will be disclosed. The $H 1$ can therefore be formulated:

H1. Business-related KPIs are disclosed by companies operating in industries with high pressure from investors and customers.

There is a general agreement in the CSR literature that companies, which operate in industries with a negative impact on the environment, generally provide more environmentrelated disclosures than companies in other sectors (Fernandez-Feijoo et al., 2013). Brammer and Pavelin (2008) found that high quality corporate environmental disclosure is primarily associated with larger firms and those in sectors most closely related to ecological concerns. According to the findings of Tagesson et al. (2009), the raw material industry provides more environmental disclosures than others included in their study. There are studies, which demonstrate the influence of stakeholder pressures on companies' environmental strategies and initiatives (Sharma and Henriques, 2005; Buysse and Verbeke, 2003; Banerjee et al., 2003). For example, Buysse and Verbeke (2003) show that more profound and broader coverage of stakeholders is associated with more proactive corporate strategies towards the environment. The findings of Banerjee et al. (2003) indicate that in the industry with high environmental impact, concerns expressed by the community stakeholders (such as ecological activists) and customers have the most significant impact on the recognition of the importance of environmental issues facing the company and their integration into its strategy. Gamerschlag et al. (2011) find that companies under the pressure of ecological groups disclose environmental information to a larger extent than the ones which are not exposed to such influences. In the case of an environmentally harmful event (e.g. an oil spill) companies were found to respond to the stakeholders who seek information by regularly updating their websites (De Villiers and Van Staden, 2011). In line with the above, it is expected that the managers' choice to disclose environment-related non-financial KPIs is likely to be affected by the industry in which the company operates, and more specifically, the environmental sensitivity of this industry. Therefore, the following can be posited:

H2. Environment-related KPIs are disclosed by companies operating in ESI. 
MEDAR

29,7

As Mishra and Suar (2010, p. 309) identify, "addressing of issues such as philanthropic giving, public-private partnerships and social and economic development of the surrounding community depicts CSR towards the community". Society-related KPIs present the influence of corporate decisions and operations on society in general. According to Lisi (2018), the perceived concern of stakeholders for issues related to the responsibility towards the community represents a strong incentive for companies to integrate social criteria into their performance measurement systems. These concerns are primarily expressed by the management and employees who are socially engaged and willing to participate in the company's social initiatives, such as, e.g. volunteering or payroll giving. The bigger the company, the stronger it is influenced by the employees, and, at the same time, the higher the social visibility and social impact. According to Haski-Leventhal (2013), employees can be a central component of CSR initiatives - not only as a group whose needs are to be addressed but also as active contributors to the company's giving and community involvement. Given the above, the $H 3$ can be formulated as follows:

H3. Society-related KPIs are disclosed by companies operating in industries with high pressure from employees.

As Williams and Adams (2013, p. 483) argue, "Companies need to demonstrate a genuine attempt to be accountable to employees, to demonstrate that they have considered and responded to the needs and concerns of employees in their decisions, policies and practices". The engagement in the CSR practice by the company's management sends signals to employees about the values of the company (Jones et al., 2014). Prior literature has focused on employees benefiting from the general corporate CSR engagement because of the support they receive as its part (Cropanzano and Rupp, 2008). Although the CSR research suggests that there is a relationship between CSR practice and employee engagement, there is a lack of studies that provide evidence on the influence of this stakeholder group on non-financial disclosures (Kent and Zunker, 2015), and specifically, on KPIs. However, an employeeoriented company will commit resources to promote employee welfare (Hooley et al., 2000) and inform a broader audience. Companies with higher employee share ownership and employee concentration were found to disclose more voluntary employee-related information (Kent and Zunker, 2015). According to some authors, employees in large companies are well-organized, and their opinions are taken into consideration while disclosing on the corporate CSR practices (Aldama et al., 2009; Ellis, 2009; Haski-Leventhal, 2013; Wei et al., 2009; Fernandez-Feijoo et al., 2013). Within a company with increased employee numbers, a larger number of employee-related events and issues are likely to occur. Thus, management is more likely to be motivated to report on employee issues (Kent and Zunker, 2015). At the same time, there is a risk that employees may react negatively towards the company because they believe management does not care about their employees' interest if management does not disclose employee-related information (Lev, 1992). In light of the above, the $H 4$ is proposed:

H4. Employee-related KPIs are disclosed by companies operating in industries with high pressure from employees.

\section{Study design}

\subsection{Sample, data collection and research method}

The initial sample consisted of 178 large PIEs operating in Poland and are required to provide non-financial disclosures according to the new accounting law. However, the 
disclosure of 9 PIEs was covered by the reports of the parent company, resulting in the total number of 169 researched companies. The list of PIEs has been provided by the Polish Ministry of Finance and is available at www.gov.pl/web/finanse/wykaz-jzp-1 (Ministry of Finance, 2020). These companies are the most advanced entities in Poland regarding the implementation of the CSR concept and the source of CSR reporting good practices.

Between June 2019 and September 2019, the sample of the companies' 2018 non-financial statements were downloaded from the website https://standardy.org.pl/raporty-spolek (FSR, 2020) in PDF format. Subsequently, a content analysis of the disclosures was performed. The focus of the analysis was on disclosures on non-financial KPIs.

To identify the non-financial KPIs, a word search was performed with the use of the following words and phrases in a source file (usually a PDF): "KPI" (in English), "key" ("kluczow*" in Polish), "indicator" ("wskaźnik*" in Polish). Coding consisted of transferring the information on KPIs included in the companies' non-financial statements to an observation sheet. The approach that was used occurs in the category of disclosure index studies (according to the division of research methods applied to the analysis of narratives in annual reports by Beattie et al. (2004, p. 32)). "A disclosure index is a research instrument comprising a series of pre-selected items which, when scored, provide a measure that indicates a level of disclosure” (Coy, 1995 as cited by Guthrie and Abeysekera, 2006, p. 118). The approach adopted by the authors of this paper differs from the above definition because of the fact that the list of KPIs evolved during the content analysis. More specifically, KPIs were determined in the pilot study based on 10 randomly selected companies, but during the course of the research, where a new KPI was identified in a subsequent company's nonfinancial statement it was added to the list in the observation sheet. When the presence or absence of an item needed to be stated, a simple binary $(0,1)$ coding scheme was used. The coding procedure was performed by the co-authors. The intercoder reliability was tested with the use of Cohen's kappa $(\kappa)$ or Krippendorff's alpha (b) (Lombard et al., 2002).

To thoroughly analyse the set of data obtained from the reports, four linear regressions have been run. They were aimed at testing the pressure of different groups of stakeholders on the disclosure of business operations, environmental, social and employee KPIs, as well as uncovering the disclosure patterns of the searched companies.

\subsection{Variables definitions and the regression model}

4.2.1 Dependent variables. Four dependent variables are the values of the disclosure indexes calculated as a result of the conducted content analysis of the corporate KPI disclosures.

The identified KPIs were classified into four main categories related to:

(1) business operations;

(2) environmental matters;

(3) society matters; and

(4) employee matters. Four disclosure indexes were calculated for every company based on the average number of the disclosed KPIs in each of the above-mentioned areas.

4.2.2 Independent variables. The focus of the four main independent variables is to serve as a proxy for stakeholder pressure with the use of the relationship between the main stakeholder groups and the industries. Data concerning the industry was collected from the companies' annual, CSR or integrated reports. In total, 24 different sectors were identified and following (Fernandez-Feijoo et al., 2013) 4 dichotomous variables were created 
MEDAR 29,7

considering the pressure on each sector of 4 groups of stakeholders (customers, employees, environment and investors). Each of them is discussed below.

Customer proximity index $(C P I)$ - the variable equals 1 if the company is a representative of a well-known industry for the wider public as a consumer of its products or services. Fernandez-Feijoo et al. (2013), Sweeney and Coughlan (2008) and Branco and Rodrigues (2008) include here such industries as: energy utilities, financial services, food and beverage products, health care, household and personal products, retailers, telecommunications, textiles and apparel, waste management, water utilities, commercial services, consumer durables, media, tobacco, tourism/leisure, toys and universities. For other industries, the variable equals 0 . "Customer proximity" has been a frequently used proxy in research on the social exposure related to industry affiliation (cf. among others: Campbell et al., 2006; Clarke and Gibson-Sweet, 1999). Branco and Rodrigues (2008) confirm a positive relationship between social engagement and the consumer proximity measure. This is because companies that are better known to the final consumer and to most members of the general public enjoy greater social visibility but also face more pressure on social involvement from those stakeholders.

$E O I$ - the variable was defined based on the size of a company to measure the pressure from the employees (Aldama et al., 2009; Ellis, 2009; Haski-Leventhal, 2013; Wei et al., 2009; Fernandez-Feijoo et al., 2013). The company's size is measured by the number of employees. Employees in large companies are assumed to be better organized and their opinions are considered by management, thus they are able to exert some pressure on the company (Huang and Kung, 2010; Aldama et al., 2009; Ellis, 2009; Haski-Leventhal, 2013; Wei et al., 2009; Fernandez-Feijoo et al., 2013). The information regarding the employment was collected from the sample companies' annual, CSR or integrated reports.

Environmentally sensitive industries (ESI) - this variable equals 1 if a company has an impact on the environment. The industries that have such an impact are: agriculture, automotive, aviation, chemical, construction, construction materials, energy, energy utilities, forest and paper products, logistics, metal products, mining, railroad, waste management and water utilities (Tagesson et al., 2009; Gamerschlag et al., 2011; Branco and Rodrigues, 2008; Fernandez-Feijoo et al., 2013). For all the other industries the variable adopts a value of 0 .

Investor-oriented industries (IOI) - this variable equals 1 for industries with a high level of pressure from their investors (Collins, 2010). These are industries in which more than $50 \%$ of companies are traded on the stock exchange. Especially for public companies, current and potential shareholders represent the primary stakeholder, thus exerting a high level of pressure (Collins, 2010; Sweeney and Coughlan, 2008). Fernandez-Feijoo et al. (2013) include here the following sectors: automotive, aviation, chemicals, computers, conglomerates, construction, construction materials, consumer durables, energy, energy utilities, financial services, health-care products, household and personal products, media, metals products, real estate, retailers, technology hardware, telecommunications, textiles and apparel and toys. For other industries, the variable adopts a value of 0 .

An additional variable has been added to this study's analysis, namely, standard (STD). The accountability frameworks, such as the GRI, recognize stakeholder inclusivity as the core principle to enhance accountability and transparency of social practices (Gao and Zhang, 2001; Rinaldi et al., 2014; Kaur and Lodhia, 2018). According to Hoffmann et al. (2018) companies that use GRI disclose more detailed information on sustainability topics in GRI-based stand-alone reports than in management commentaries. Companies in Poland can also use local Standard Informacji Niefinansowych (Non-financial Information Standard - NFIS) [3]. Therefore, it is assumed that companies that present CSR information with the use of GRI guidelines not only identify their stakeholders but also engage them in CSR practices and respond to the key topics and concerns that have been raised through stakeholder engagement and disclose KPIs on 
these issues. STD variable is equal to 1 if the company uses GRI, NFIS or another framework to present CSR information and 0 if the company implemented its own approach to reporting. The same approach was used by Vurro and Perrini (2011).

The following Table 1 summarizes the variables and their measurement.

\section{Key \\ performance indicators}

\begin{tabular}{|c|c|c|c|c|c|c|}
\hline Variable & $\begin{array}{l}\text { Variable } \\
\text { function }\end{array}$ & Description & Measurement & $\begin{array}{l}\text { Original } \\
\text { scale }\end{array}$ & References & 11 \\
\hline$B O \_K P I$ & $\begin{array}{l}\text { Dependent/ } \\
\text { independent }\end{array}$ & $\begin{array}{l}\text { Disclosure } \\
\text { index of } \\
\text { business- } \\
\text { related KPIs }\end{array}$ & $\begin{array}{l}\text { Average number of the } \\
\text { KPIs related to } \\
\text { business operations } \\
\text { disclosed by the } \\
\text { sample companies }\end{array}$ & Metric & $\begin{array}{l}\text { Guthrie and Abeysekera } \\
\text { (2006) }\end{array}$ & \\
\hline$E N V \_K P I$ & $\begin{array}{l}\text { Dependent/ } \\
\text { independent }\end{array}$ & $\begin{array}{l}\text { Disclosure } \\
\text { index of } \\
\text { environment- } \\
\text { related KPIs }\end{array}$ & $\begin{array}{l}\text { Average number of the } \\
\text { KPIs related to } \\
\text { environmental matters } \\
\text { disclosed by the } \\
\text { sample companies }\end{array}$ & Metric & $\begin{array}{l}\text { Guthrie and Abeysekera } \\
\text { (2006) }\end{array}$ & \\
\hline$S O C \_K P I$ & $\begin{array}{l}\text { Dependent/ } \\
\text { independent }\end{array}$ & $\begin{array}{l}\text { Disclosure } \\
\text { index of } \\
\text { society- } \\
\text { related KPIs }\end{array}$ & $\begin{array}{l}\text { Average number of the } \\
\text { KPIs related to social } \\
\text { matters disclosed by } \\
\text { the sample companies }\end{array}$ & Metric & $\begin{array}{l}\text { Guthrie and Abeysekera } \\
(2006)\end{array}$ & \\
\hline$E M P \_K P I$ & $\begin{array}{l}\text { Dependent/ } \\
\text { independent }\end{array}$ & $\begin{array}{l}\text { Disclosure } \\
\text { index of } \\
\text { employees- } \\
\text { related KPIs }\end{array}$ & $\begin{array}{l}\text { Average number of the } \\
\text { KPIs related to } \\
\text { employee matters } \\
\text { disclosed by the } \\
\text { sample companies }\end{array}$ & Metric & $\begin{array}{l}\text { Guthrie and Abeysekera } \\
\text { (2006) }\end{array}$ & \\
\hline$E O I$ & Independent & $\begin{array}{l}\text { Employee- } \\
\text { oriented } \\
\text { industry }\end{array}$ & Number of employees & Metric & $\begin{array}{l}\text { Aldama } \text { et al. (2009), Ellis } \\
\text { (2009), Haski-Leventhal } \\
\text { (2013), Wei } \text { et al. (2009), } \\
\text { Fernandez-Feijoo et al. } \\
\text { (2013), Huang and Kung } \\
\text { (2010) }\end{array}$ & \\
\hline$E S I$ & Independent & ESI & $\begin{array}{l}1=\text { environmentally } \\
\text { sensitive industries } \\
0=\text { other industry }\end{array}$ & Dichotomous & $\begin{array}{l}\text { Tagesson et al. (2009), } \\
\text { Gamerschlag et al. (2011), } \\
\text { Branco and Rodrigues } \\
\text { (2008), Fernandez-Feijoo } \\
\text { et al. (2013) }\end{array}$ & \\
\hline$C P I$ & Independent & $\begin{array}{l}\text { Consumer- } \\
\text { proximity } \\
\text { industries }\end{array}$ & $\begin{array}{l}1=\text { consumer- } \\
\text { proximity industries } \\
0=\text { other industry }\end{array}$ & Dichotomous & $\begin{array}{l}\text { Fernandez-Feijoo et al. } \\
\text { (2013), Sweeney and } \\
\text { Coughlan (2008), Branco } \\
\text { and Rodrigues (2008), } \\
\text { Campbell } \text { et al. (2006), } \\
\text { Clarke and Gibson-Sweet } \\
\text { (1999) }\end{array}$ & \\
\hline$I O I$ & Independent & $\begin{array}{l}\text { Investor- } \\
\text { oriented } \\
\text { industry }\end{array}$ & $\begin{array}{l}1=\text { investor-oriented } \\
\text { industry } \\
0=\text { other industry }\end{array}$ & Dichotomous & $\begin{array}{l}\text { Fernandez-Feijoo et al. } \\
\text { (2013), Collins (2010), } \\
\text { Sweeney and Coughlan } \\
\text { (2008) }\end{array}$ & \\
\hline$S T D$ & Independent & $\begin{array}{l}\text { Reporting } \\
\text { standard }\end{array}$ & $\begin{array}{l}1=\text { company uses GRI } \\
\text { or other framework } \\
0=\text { company uses own } \\
\text { approach }\end{array}$ & Dichotomous & $\begin{array}{l}\text { Gao and Zhang (2001), } \\
\text { Rinaldi et al. (2014), Kaur } \\
\text { and Lodhia (2018), } \\
\text { Hoffmann et al. (2018), } \\
\text { Vurro and Perrini (2011) }\end{array}$ & $\begin{array}{r}\text { Table } 1 . \\
\text { Overview of } \\
\text { variables used in the } \\
\text { empirical study }\end{array}$ \\
\hline
\end{tabular}


MEDAR 29,7

4.2.3 Model. The test of the hypothesis searches if the engagement of different stakeholder groups has an effect on the disclosures of KPIs and examines the disclosures patterns. Four linear regressions were run:

Regression 1:

$$
\text { BO_KPI }=b_{0}+b_{1} \mathrm{EOI}+\mathrm{b}_{2} \mathrm{ESI}+\mathrm{b}_{3} \mathrm{CPI}+\mathrm{b}_{4} \mathrm{IOI}+\mathrm{b}_{5} \mathrm{STD}+\mathrm{b}_{6} \mathrm{ENV} \text { KPI }
$$

$$
+\mathrm{b}_{7} \mathrm{SOC} \_\mathrm{KPI}+\mathrm{b}_{8} \mathrm{EMP} \_\mathrm{KPI}+\xi_{0}
$$

Regression 2:

$$
\begin{aligned}
\mathrm{ENV} \_\mathrm{KPI}= & \mathrm{b}_{0}+\mathrm{b}_{1} \mathrm{EOI}+\mathrm{b}_{2} \mathrm{ESI}+\mathrm{b}_{3} \mathrm{CPI}+\mathrm{b}_{4} \mathrm{IOI}+\mathrm{b}_{5} \mathrm{STD}+\mathrm{b}_{6} \mathrm{BO} \_\mathrm{KPI} \\
& +\mathrm{b}_{7} \mathrm{SOC} \_\mathrm{KPI}+\mathrm{b}_{8} \mathrm{EMP} \_\mathrm{KPI}+\xi_{0}
\end{aligned}
$$

Regression 3:

$$
\begin{aligned}
\text { SOC_KPI }= & b_{0}+b_{1} E O I+b_{2} E S I+b_{3} C P I+b_{4} I O I+b_{5} \text { STD }+b_{6} \text { EMP_KPI } \\
& +b_{7} \text { ENV_KPI }+b_{8} \text { BO_KPI }+\xi_{0}
\end{aligned}
$$

Regression 4:

$$
\begin{aligned}
\mathrm{EMP} \_K P I= & \mathrm{b}_{0}+\mathrm{b}_{1} \mathrm{EOI}+\mathrm{b}_{2} \mathrm{ESI}+\mathrm{b}_{3} \mathrm{CPI}+\mathrm{b}_{4} \mathrm{IOI}+\mathrm{b}_{5} \mathrm{STD}+\mathrm{b}_{6} \mathrm{SOC} \_\mathrm{KPI} \\
& +\mathrm{b}_{7} \mathrm{ENV} \_\mathrm{KPI}+\mathrm{b}_{8} \mathrm{BO} \_\mathrm{KPI}+\xi_{0}
\end{aligned}
$$

\section{Results}

\subsection{Descriptive statistics}

5.1.1 Key performance indicators related to business operations. A total of 204 different KPIs related to corporate business operations were identified (Table 2) and were divided into 13 areas as indicated in the table. Companies most frequently present KPIs associated with their products and services. Those KPIs are usually expressed as a simple ratio showing the number of units and services provided to the clients. Some companies report the number of product improvements introduced in the recent period. The second important group of ratios are KPIs related to the clients' care and satisfaction. The most frequently used indicators in this area are net promotes score (NPS) and the number of clients. KPIs linked to sales focus on information concerning the percentage of export and online sales in the total sales. Concerning distribution channels, the number of shops, branches and other units in the sales network is often reported. In the majority of the studied cases, the investments are presented as a ratio of capital expenditure to sales revenues. The KPIs associated with the suppliers' relations are expressed most often as the total number of suppliers and the percentage of local suppliers. Several companies present KPIs related to the market share and number of markets in which they operate. Quality KPIs are represented by the number of product controls and the number of hours of control. Companies included in the sample disclose some working capital ratios, mainly inventory turnover period in days, receivables collection period in days and payables payment period in days. KPIs on the production provide information regarding the number of production sites, as well as material and energy consumption in the production processes. Finally, warranty and customer service are represented by the ratio of warranties to sales and indicators of timeliness of complaint processing. 


\begin{tabular}{|c|c|c|c|c|c|c|c|}
\hline KPIs & No. of KPIs & $\begin{array}{c}\text { No. of } \\
\text { observations }\end{array}$ & Max. & Min. & Mean & SD & performance \\
\hline \multicolumn{8}{|l|}{ Business-related KPIs } \\
\hline Investments & 16 & 26 & 4 & 0 & 0.154 & 0.512 & \multirow{10}{*}{13} \\
\hline Warranties and customers service & 8 & 18 & 4 & 0 & 0.225 & 0.643 & \\
\hline Working capital management & 10 & 12 & 4 & 0 & 0.071 & 0.387 & \\
\hline Suppliers relations & 13 & 32 & 2 & 0 & 0.189 & 0.488 & \\
\hline Sales/marketing/distribution & 51 & 91 & 7 & 0 & 0.538 & 1.107 & \\
\hline Clients care/satisfaction & 29 & 52 & 8 & 0 & 0.308 & 0.906 & \\
\hline Production & 9 & 16 & 3 & 0 & 0.154 & 0.476 & \\
\hline Quality & 11 & 20 & 4 & 0 & 0.118 & 0.498 & \\
\hline Products/services offered & 38 & 58 & 6 & 0 & 0.349 & 0.940 & \\
\hline Others & 19 & 47 & 3 & 0 & 0.219 & 0.612 & \\
\hline \multicolumn{8}{|l|}{ Environment-related KPIs } \\
\hline Emissions & 10 & 147 & 4 & 0 & 0.941 & 1.084 & \\
\hline Water use & 9 & 76 & 2 & 0 & 0.450 & 0.587 & \\
\hline Wastewater & 6 & 33 & 3 & 0 & 0.195 & 0.466 & \\
\hline Materials and products & 21 & 75 & 3 & 0 & 0.444 & 0.680 & \\
\hline Energy use & 26 & 133 & 4 & 0 & 0.787 & 0.888 & \\
\hline Package and waste & 57 & 216 & 8 & 0 & 1.172 & 1.452 & \\
\hline $\begin{array}{l}\text { Environmental investments, } \\
\text { malfunctions, penalties }\end{array}$ & 25 & 55 & 8 & 0 & 0.355 & 1.008 & \\
\hline \multicolumn{8}{|l|}{ Society-related KPIs } \\
\hline Charity and sponsoring & 7 & 46 & 2 & 0 & 0.272 & 0.497 & \\
\hline Volunteering & 6 & 22 & 5 & 0 & 0.130 & 0.562 & \\
\hline Social initiatives, grants, investments & 26 & 42 & 9 & 0 & 0.249 & 0.950 & \\
\hline Complaints and nuisances & 4 & 9 & 2 & 0 & 0.053 & 0.273 & \\
\hline \multicolumn{8}{|l|}{ Employees-related KPIs } \\
\hline Accidents & 93 & 450 & 14 & 0 & 2.580 & 3.252 & \multirow{9}{*}{$\begin{array}{l}\text { Table } 2 . \\
\text { Details concerning } \\
\text { the identified KPIs }\end{array}$} \\
\hline Training & 44 & 210 & 7 & 0 & 1.249 & 1.647 & \\
\hline Employment & 83 & 815 & 17 & 0 & 5.077 & 3.858 & \\
\hline Salaries & 23 & 76 & 4 & 0 & 0.450 & 0.852 & \\
\hline Leaves & 8 & 34 & 4 & 0 & 0.201 & 0.613 & \\
\hline Employees' assessments & 12 & 21 & 6 & 0 & 0.124 & 0.619 & \\
\hline Corruption, ethics, mobbing, discrimination & 70 & 105 & 18 & 0 & 0.621 & 1.970 & \\
\hline Corporate boards & 15 & 29 & 2 & 0 & 0.170 & 0.480 & \\
\hline Trade unions and employee' benefits & 32 & 74 & 7 & 0 & 0.438 & 1.117 & \\
\hline
\end{tabular}

5.1.2 Key performance indicators related to environmental matters. Companies included in the sample present 154 different environmental KPIs in total (Table 2) and refer to 8 categories: emissions, water use, wastewater, materials and products, energy use, package and waste, environmental investments, malfunctions, controls and penalties. Companies most frequently present KPIs related to packages and waste. KPIs linked to waste are most often divided into two groups: hazardous and non-hazardous, and also according to its disposal. KPIs are usually expressed in tonnes but also as a relation of the total amount of waste to the unit of production or revenue. Regarding emissions, the amount of carbon dioxide is most frequently presented, followed by information on other selected substances. KPIs are usually expressed in Megagrams (Mgs), however, similar to the above, some companies also present the amount of emissions in relation to the unit of production or revenues. The use of energy is presented with the KPIs differentiated according to the energy source: electricity, fuels and natural gases. KPIs are expressed in the natural units 
MEDAR

29,7

and also related to the revenues (e.g. PLN 1,000 or PLN 1,000,000) or to the number of clients. Three companies present the "energy efficiency" indicators and two companies present the "intensiveness of the energy use" indicators. The KPIs associated with the use of water are expressed most often as the total amount. Only a few companies differentiate its use according to the source or relate it to the number of employees, units of production or revenues. The KPIs related to materials and products are reported equally often as those related to the use of water. The next KPI category is quite diverse as it comprises of several aspects related to environmental disclosures such as environmental investments, malfunctions, controls and penalties. Out of these, the number of penalties related to the environment were most often presented.

5.1.3 Key performance indicators related to social matters. In total, 43 different KPIs disclosed by companies with regard to relations with society were able to be identified (Table 2). They cover four areas: charity and sponsoring; volunteering; social initiatives, grants, investments; complaints and penalties. Traditionally the CSR activities in Poland are linked to charity and sponsorships. Within this sub-category, companies disclose the total amount of money given to charity or in a relative form, divided by the total revenue. Employees' engagement in volunteering was measured in different ways - as a number of volunteers, the number of projects realized or applications submitted. However, the most frequently used KPI is the one based on the number of volunteering hours. Companies also use non-financial KPIs to provide information regarding various social initiatives, grants and scholarships offered to the local communities or social investments. KPIs most often used under this sub-category are the number of beneficiaries and the number of social initiatives supported. The corporate relationship with society is not only positive but it may also have negative aspects. Companies included in the sample disclose the number of complaints issued by the local communities, which were filed or filed and examined, administrative proceedings against them and potential nuisances for the local communities.

5.1.4 Key performance indicators related to employee matters. The largest number of KPIs is used to present the companies' relations with employees - 380 different indicators in total (Table 2). They refer to 10 categories: accidents; training; employment; salaries and benefits; employees' assessments; corruption, ethics, mobbing, discrimination; trade unions; corporate boards; others. In total, 83 different KPIs are used to present the level and structure of employment and related changes. Employees are typically differentiated according to the gender, age, job seniority, place of work (organizational unit (segment) or geographical location such as region or town), the position, type of contract, type of job (full time vs part-time; permanent vs temporary), nationality (Poles vs foreigners) or education. Another important aspect is employee rotation. It was presented as a single KPI but also segregated, most often according to the gender, age, type of contract or operational segment. Several companies also present KPIs related to the recruitment procedures such as the number of employees internally recruited, the number of interns (according to gender, localization and whether they were employed after the internship or not), the number of paid and unpaid internships, the number of received/verified applications, the average recruitment time, the efficiency of the recruitment process after completing the internship program.

The next important area of disclosure is work accidents. The number of accidents is the most often presented KPI in this area, followed by the number of fatal, severe and minor accidents. Companies most often calculate the lost time injury frequency rate with the use of the following formula: the number of lost time injuries multiplied by $1,000,000$, divided by the employee total hours worked. Another version of the KPI related to a similar problem process safety events rate is also provided. One more commonly used KPI in this area of 
disclosure is accident severity rate. Other frequently disclosed KPIs include the number and indicators related to occupational diseases, the number of days' inability to work related to accidents at work or number of potentially accidental incidents. KPIs related to occupational health and safety (OHS) training are also disclosed. They refer to the number of employees who participated in such trainings, number of hours and e.g. number of penalties imposed on companies for violating OHS rules. The obligation to create an employee-friendly environment, including the provision of possible personal development, is also an important area of non-financial reporting. The most frequently used KPI linked to this problem presents the average number of training hours per employee. As regard the frequency of appearance, it is followed by the number of trained employees (according to the gender and workplace) and the total number of training sessions.

Another important area of employee-related disclosure is linked to salaries and other benefits. The KPI most frequently used is the average salary, followed by the "ratio of average gross salary of women to average gross salary of men in particular grade categories/employee groups" and the "ratio of the average remuneration of board members to the lowest salary in a company". As regard leave taken by employees, six KPIs out of eight that were identified are linked to parental leave with "returns and retention after maternity/parental leave" being the most frequently reported. Others related to the number of employees currently on maternity/parental/paternity leave or e.g. "the percentage of women who resigned from work within 12 months of returning to work after having a child".

Another group of KPIs disclosed by companies included in the sample relating to corruption, ethics, mobbing or discrimination. Most frequently used KPIs refer to the number of reports of corruption, mobbing or discrimination cases. Some companies also disclosed as a KPI the number of non-ethical behaviour cases, the percentage of employees who underwent anti-corruption training or the number of complaints regarding human rights violations. KPIs also represented the companies' unionization with the use of the number (or percentage) of employees belonging to trade unions and the total number of trade unions operating in the company. The number of strikes and the number of days lost due to strikes are also presented. As far as the benefits are concerned, companies frequently disclosed KPIs related to medical care (e.g. number of employees covered by medical care), co-financing of sport or fringe benefits. There are also some KPIs that refer to the corporate boards, such as diversity in management bodies or the percentage of people from the local community in senior management positions at major business locations. Other KPIs include an employee education rate, profitability of labour costs, the profitability of human capital or an employee productivity indicator.

In summary, the following best practices can be identified as regard the non-financial KPI disclosures by the sample companies. Some provided transparent disclosures by selecting approximately ten high quality, broadly recognized KPIs (such as indicators used in the sector or for specific thematic issues) that are relevant and useful for stakeholders, as well as comparable within the same sector. Furthermore, the disclosure was supplemented with the information on the method of measurement, past and target values, as well as a narrative commentary explaining the relevance of the KPIs. The list of KPIs was presented in a table previously shown.

The areas that seem to pose the most significant challenges as regard KPI disclosures are the variety of the KPIs included in reporting and the method of disclosure, which makes the information provided difficult to analyse. The common approach is to present KPIs which are available to the company or easily accessible and not necessarily those of real importance. The disclosed KPIs are also spread across the whole non-financial statement, 
MEDAR

29,7

(1)

which makes their analysis difficult. Stakeholders seek transparent, comparable and reliable information on which non-financial indicators are truly "key" and influence corporate operational and strategic decisions. Unfortunately, some companies provide many different non-financial indicators but without any explanation as to how and why they are used by the management.

\section{$16 \quad 5.2$ Correlation analysis}

Table 3 provides correlations between all variables. It is apparent that the largest correlation exists between ESI and CPI. Significant correlations exist between ENV_KPI and EMP_KPI, as well as between SOC_KPI and EMP_KPI.

$V I F$ calculated for independent variables shows no multicollinearity in the tested models (the values are below 2.05). If VIF value exceeds 4.0 or is by tolerance less than 0.2 then there is a problem with multicollinearity (Hair et al., 2010).

\subsection{The results of the linear regressions}

The results of the estimation of the first linear regression are presented in Table 4, showing a positive and significant effect of investors' influence on the disclosure of business-related KPI. The variables used for analysis were standardized.

The positive sign of the coefficient shows that investors positively affect disclosure on business operations with the use of KPIs. This result indicates the existence of pressure from the financial markets to increase the confidence level of investors by increasing the

\begin{tabular}{|c|c|c|c|c|c|c|c|c|c|c|}
\hline \multirow{10}{*}{$\begin{array}{l}\text { Table } 3 \text {. } \\
\text { Correlations between } \\
\text { variables }\end{array}$} & Variables & EOI & ESI & IOI & STD & CPI & BO_KPI & ENV_KPI & SOC_KPI & EMP_KPI \\
\hline & $E O I$ & 1.000 & -0.051 & -0.035 & 0.050 & 0.254 & 0.185 & 0.024 & 0.246 & 0.053 \\
\hline & ESI & -0.051 & 1.000 & 0.081 & 0.025 & -0.669 & -0.152 & 0.265 & -0.079 & 0.180 \\
\hline & $I O I$ & -0.035 & 0.081 & 1.000 & -0.012 & 0.008 & 0.149 & -0.025 & 0.013 & -0.021 \\
\hline & STD & 0.050 & 0.025 & -0.012 & 1.000 & -0.056 & 0.095 & 0.219 & 0.028 & 0.213 \\
\hline & $C P I$ & 0.254 & -0.669 & 0.008 & -0.056 & 1.000 & 0.204 & -0.144 & 0.172 & -0.072 \\
\hline & BO_KPI & 0.185 & -0.152 & 0.149 & 0.095 & 0.204 & 1.000 & -0.137 & 0.100 & -0.048 \\
\hline & $E N V \_K P I$ & 0.024 & 0.265 & -0.025 & 0.219 & -0.144 & -0.137 & 1.000 & 0.225 & 0.594 \\
\hline & SOC_KPI & 0.246 & -0.079 & 0.013 & 0.028 & 0.172 & 0.100 & 0.225 & 1.000 & 0.402 \\
\hline & $E M P \_K P I$ & 0.053 & 0.180 & -0.021 & 0.213 & -0.072 & -0.048 & 0.594 & 0.402 & 1.000 \\
\hline
\end{tabular}

Regression Summary for dependent variable: $B O \_K P I$

\begin{tabular}{|c|c|c|c|c|c|c|}
\hline \multirow[b]{2}{*}{$N=169$} & \multicolumn{6}{|c|}{$\begin{array}{c}\text { Regression Summary for dependent variable: } B O \_K P I \\
R=0.344 R^{2}=0.128 \text { Adjusted } R^{2}=0.074 \mathrm{~F}(8.160)=2.680 p<0.0086 \text { Std. error of estimate: } 0.191\end{array}$} \\
\hline & $b^{*}$ & Std. error of $b^{*}$ & $b$ & Std. error of $b$ & $t(160)$ & $p$-value \\
\hline \multicolumn{3}{|l|}{ Intercept } & 0.051 & 0.049 & 1.035 & 0.302 \\
\hline$E O I$ & 0.139 & 0.080 & 0.000 & 0.000 & 1.731 & 0.085 \\
\hline ESI & -0.037 & 0.106 & -0.015 & 0.042 & -0.354 & 0.724 \\
\hline$C P I$ & 0.114 & 0.106 & 0.045 & 0.042 & 1.079 & 0.282 \\
\hline$I O I$ & 0.153 & 0.075 & 0.064 & 0.031 & 2.041 & $0.043 * *$ \\
\hline$S T D$ & 0.130 & 0.077 & 0.056 & 0.034 & 1.682 & 0.094 \\
\hline SOC_KPI & 0.073 & 0.085 & 0.126 & 0.147 & 0.858 & 0.392 \\
\hline$E M P \_K P I$ & -0.004 & 0.100 & -0.004 & 0.104 & -0.038 & 0.970 \\
\hline$E N V \_K P I$ & -0.152 & 0.095 & -0.118 & 0.073 & -1.604 & 0.111 \\
\hline \multicolumn{7}{|c|}{ Note: $* * p<0.05$} \\
\hline
\end{tabular}

Table 4.

The results of estimation of Regression 1

Note: $* * p<0.05$ 
disclosure on the business operations (Fernandez-Feijoo et al., 2013; Curtis et al., 2014; $\mathrm{Wu}, 2012)$. A similar relation as regard the customers' pressures was unable to be identified by the authors of this paper. Consequently, the $H 1$, according to which business-related KPIs are disclosed by companies operating in industries with high pressure from both investors and customers, is only partially supported. The statistical results provided by the equation testing the hypothesis show that equation (1) represents a relatively low degree of explanation because the adjusted R-squared $\left(R^{2}\right)$ equals 0.128 . The model used collectively explains $12.8 \%$ of the variability of the BO_KPI around its mean.

The results of the estimation of the second linear regression are presented in Table 5, showing a positive and significant influence of the fact that the company belongs to the environmentally sensitive industry and discloses employee-related KPIs on the disclosure of environment-related KPIs. The variables were standardized.

Regression 2 confirms that companies operating in ESI present KPIs related to environmental issues to mitigate the public perception of their detrimental impact on the environment. This finding is in line with the results of the studies conducted by Fernandez-Feijoo et al. (2013), Gamerschlag et al. (2011), Tagesson et al. (2009), Sharma and Henriques (2005), Buysse and Verbeke (2003) and Banerjee et al. (2003). Thus, the H2, which states that environment-related KPIs are disclosed by companies operating in ESI, is supported. Interestingly, the disclosure on KPIs related to environmental issues is spurred by reporting on employee matters. In other words, companies disclosing on employee matters disclose also on environmental issues with the use of KPIs. This might be due to the fact that environmental sensitivity can also pose a danger to the employees due to the use of machines (in such industries as construction, mining, automotive) or harmful substances (e.g. in the chemical industry). The statistical results provided by the equation testing the hypothesis show that Regression 2 represents a relatively high degree of explanation because the $R^{2}$ equals 0.399 . The model used collectively explains $39.9 \%$ of the variability of the ENV_KPI around its mean.

The results of the estimation of Regression 3 are presented in Table 6 and show a positive and significant effect of the fact that the company belongs to the employee-oriented industry and provides employee-related disclosures in the form of KPI on the disclosure of society-related KPIs. The variables were standardized.

The positive signs of the coefficients show that employees and the disclosure of employee-related KPIs positively affect disclosure of society-related KPIs. Regression 3

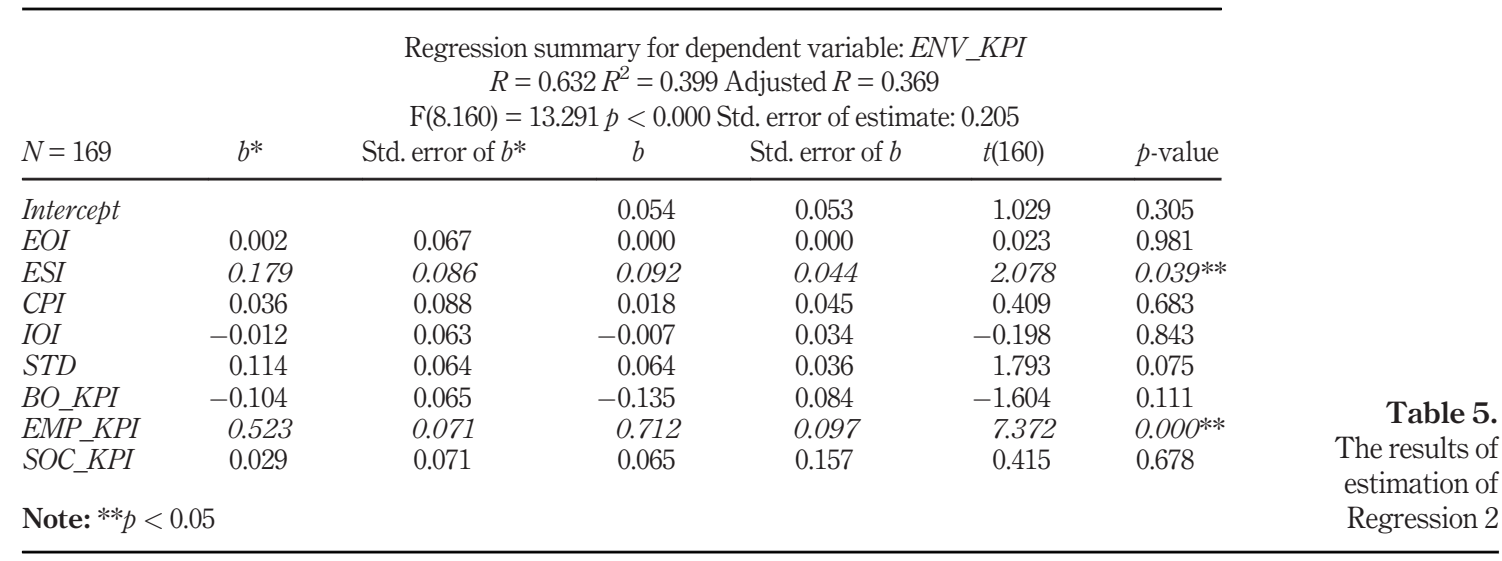


MEDAR 29,7

18

confirms that the larger the number of employees, the higher the pressure on social issues disclosure. The companies which are larger have resources to provide social support and contribute to the charity. Therefore, it seems reasonable that they more often disclose societyrelated KPIs and provide higher levels of disclosure. This finding also supports the results of previous studies (Aldama et al., 2009; Ellis, 2009; Haski-Leventhal, 2013; Fernandez-Feijoo et al., 2013; Lisi, 2018). Thus, the H3, which states that society-related KPIs are disclosed by companies operating in industries with high pressure from employees, is supported. Interestingly, the disclosure of KPIs related to social issues is triggered by the reporting on employee matters. Companies which disclose employee-related KPIs, also disclose on social issues. This might be due to the fact that more extensive disclosures on employees are usually provided by larger companies which are also more actively involved in supporting the local communities. The statistical results provided by the equation testing the hypothesis show that equation (2) represents a relatively high degree of explanation because the $R^{2}$ equals 0.246 . The model used collectively explains $24.6 \%$ of the variability of the SOC_KPI around its mean.

The results of the estimation of the fourth linear regressions are presented in Table 7. A positive and significant effect is shown on the disclosure of KPIs related to social and

\begin{tabular}{|c|c|c|c|c|c|c|}
\hline \multirow[b]{2}{*}{$N=169$} & \multicolumn{6}{|c|}{$\begin{array}{l}\text { Regression summary for dependent variable: } S O C \_K P I \\
\qquad R=0.496 R^{2}=0.246 \text { Adjusted } R^{2}=0.208 \\
\mathrm{~F}(8.160)=6.533 p<0.000 \text { Std. error of estimate: } 0.103\end{array}$} \\
\hline & $b^{*}$ & Std. error of $b^{*}$ & $b$ & Std. error of $b$ & $t(160)$ & $p$-value \\
\hline Intercept & & & -0.015 & 0.026 & $-0,579$ & 0,564 \\
\hline$E O I$ & 0,191 & 0,073 & 0,000 & 0,000 & 2,609 & $0,010^{* *}$ \\
\hline$E S I$ & -0.090 & 0.097 & -0.021 & 0.023 & -0.921 & 0.359 \\
\hline$C P I$ & 0.081 & 0.098 & 0.019 & 0.023 & 0.827 & 0.410 \\
\hline$I O I$ & 0.025 & 0.070 & 0.006 & 0.017 & 0.358 & 0.721 \\
\hline$S T D$ & -0.076 & 0.072 & -0.019 & 0.018 & -1.065 & 0.289 \\
\hline BO_KPI & 0.063 & 0.073 & 0.036 & 0.042 & 0.858 & 0.392 \\
\hline$E N V \_K P I$ & 0.037 & 0.089 & 0.017 & 0.040 & 0.415 & 0.678 \\
\hline$E M P \_K P I$ & 0.412 & 0.086 & 0.251 & 0.053 & 4.783 & $0.000^{* *}$ \\
\hline Note: $* * p$ & & & & & & \\
\hline
\end{tabular}

Table 6.

The results of estimation of Regression 3

\begin{tabular}{|c|c|c|c|c|c|c|}
\hline \multirow[b]{2}{*}{$N=169$} & \multicolumn{6}{|c|}{$\begin{array}{c}\text { Regression summary for dependent variable: EMP_KPI } \\
\qquad \begin{aligned} R & =0.666 R^{2}=0.444 \text { Adjusted } R^{2}=0.416 \\
\mathrm{~F}(8.160) & =15.951 p<0.000 \text { Std. error of estimate: } 0.145\end{aligned}\end{array}$} \\
\hline & $b^{*}$ & Std. error of $b^{*}$ & $b$ & Std. error of $b$ & $t(160)$ & $p$-value \\
\hline Intercept & & & 0.051 & 0.037 & 1.384 & 0.168 \\
\hline$E O I$ & -0.038 & 0.064 & 0.000 & 0.000 & -0.600 & 0.549 \\
\hline ESI & 0.085 & 0.084 & 0.032 & 0.032 & 1.021 & 0.309 \\
\hline CPI & 0.019 & 0.084 & 0.007 & 0.032 & 0.222 & 0.825 \\
\hline$I O I$ & -0.019 & 0.060 & -0.008 & 0.024 & -0.319 & 0.750 \\
\hline STD & 0.099 & 0.061 & 0.041 & 0.025 & 1.613 & 0.109 \\
\hline BO_KPI & -0.002 & 0.063 & -0.002 & 0.060 & -0.038 & 0.970 \\
\hline$E N \bar{V} \_K P I$ & 0.485 & 0.066 & 0.356 & 0.048 & 7.372 & $0.000^{* *}$ \\
\hline SOC_KPI & 0.304 & 0.064 & 0.498 & 0.104 & 4.783 & $0.000^{* * *}$ \\
\hline
\end{tabular}


environmental matters on the disclosure of employees-related KPIs. The variables were standardized.

The positive sign of the coefficients shows that there is a positive association between the disclosure on KPIs related to environmental matters and social issues and the employeerelated KPI disclosures. Confirmation was not able to be established between the relationship of the employee-related KPI disclosure and the employees' pressure. Therefore, the H4, according to which employee-related KPIs are disclosed by companies operating in industries with high pressure from employees, is not supported. However, Regression 4 reveals a positive correlation between disclosures on KPIs related to employees, society and the environment. This interesting finding might suggest that the corporate awareness of these three non-financial issues is somehow related and business operations are a somewhat distinct area. It makes sense when considering the information content of these disclosures. The statistical results provided by the equation testing the hypothesis show that Regression 4 represents a relatively high degree of explanation because the $R^{2}$ equals 0.444 . The model used collectively explains $44.4 \%$ of the variability of the EMP_KPI around its mean.

\section{Conclusions}

The non-financial disclosures can be offered to the stakeholders in narrative or non-narrative forms, such as indicators or indices. Such indicators and indices are tools extensively used in official statistics, management, policy evaluation and communication. They attempt to capture in a quantitative form various aspect of corporate performance (Scott et al., 2014). In the context of the EU Directive, they are referred to as KPIs. Their disclosure is crucial to achieve the regulations' aims, which are increased comparability and accountability across EU companies. However, as one may argue, these are both important, but somewhat contradictory aims. Stakeholders need forward-looking nonfinancial information on KPIs to compare and evaluate companies' non-financial performance. At the same time, there is no universal set of KPIs that can be used by all companies. The lack of such a list does not enhance the comparability of disclosures, but at the same time allows companies to respond better to their stakeholders' information needs, in line with the accountability notion.

In this paper, we have analysed the effect of stakeholder pressure on the disclosure of KPIs and patterns of this disclosure in researched companies using a managerial branch of stakeholder theory (Ditlev-Simonsen and Wenstøp, 2013; Nielsen and Thomsen, 2007; Miles, 2019). The data was collected from 2018 reports of 169 companies from 24 different industries that presented in a total of 781 different KPIs. The KPIs were classified into four categories related to business operations, environmental matters, social issues and employees, which enabled the calculation of KPI disclosure indexes in each area. The disclosure was tested using nine variables. Following Fernandez-Feijoo et al. (2013), four independent variables were defined as a result of the industry categorization that reflects the existence or not of stakeholder pressure. These four categories represent the impact of customers, employees, the environment and investors on companies operating in particular industries. The next four independent variables tested the correlation between different groups of disclosed KPIs. The independent variable representing standard was included in the analysis to understand the impact of stakeholder-oriented reporting frameworks on the disclosure of KPIs.

The industry is usually perceived as the factor influencing the disclosure on CSR practices, especially in the case of ESI (Tagesson et al., 2009; Gamerschlag et al., 2011; Fernandez-Feijoo et al., 2013). Our research confirms the effect of the environmental variable on the disclosure of environment-related KPIs. Moreover, the results suggest the importance of employees as a driver for disclosing society-related KPI disclosure. This finding supports the results of previous studies (Aldama et al., 2009; Ellis, 2009; Haski-Leventhal, 2013; 
MEDAR 29,7
Fernandez-Feijoo et al., 2013). Investors were identified as the source of external pressures imposed on companies which result in the disclosure on business-related KPIs. This finding is in line with the result obtained by Fernandez-Feijoo et al. (2013) who investigated the nonfinancial disclosures in general. Interestingly, there is a correlation between social, employee and environmental KPI disclosures. When the companies disclose KPIs on environmental and social issues, intensely report on employee matters. In other words, the reporting on employee matters with the use of related KPIs is accompanied by environmental and social KPI disclosures. Thus, this finding reveals patterns of disclosure of the sample companies informing when and how stakeholder pressures matter. The presentation of businessrelated KPIs is aimed at increasing the trust of investors, while environmental KPIs at moderating the negative perception of companies' harmful impact on the environment. Larger companies, with more pressure from employees, are more engaged in social and charitable practices on which they report intensely. Finally, social, environmental and employee-related KPI disclosures are correlated supporting the view that this pattern of disclosure is used to legitimize the operation of the firms among employees and the wider society. Interestingly, there is no clear evidence of the pressure of customers and applied standard on the disclosures of KPIs. Thus, the second and third hypotheses are fully supported, while the first is only partially supported. The $H 4$ is not supported, as contrary to our expectations, we are not able to state that employee-related KPIs are disclosed by companies operating in industries with high pressure from employees.

This study provides new insights into when and how stakeholders pressures matter for the non-financial KPI disclosures in a new and relatively unexplored institutional setting and in this way it contributes to the CSR literature (Lisi, 2018; Chang et al., 2014; Arvidsson, 2011; Nielsen et al., 2017). The managerial branch of stakeholder theory explains our results because we are able to state that stakeholders' environmental and social concerns impact on the use of the KPIs for measuring corporate social practices. This relation was also found by previous studies (Thomson, 2007; Fernandez-Feijoo et al., 2013; Lisi, 2018). Our results suggest that, despite the fact that KPIs rely to a large extent on the company's internal context, and in particular, the managers' decisions, the stakeholders' expectations and the need to address them are also relevant. We share the view that previous studies, which focused mainly on non-financial disclosures in general, are not representative of the problem. Due to the different nature of narrative disclosures and KPIs, stakeholder pressures concerning non-financial issues might be better reflected in external narrative reporting. KPIs are more embedded in the companies' internal business operations, and consequently, the stakeholders' influence on their use might not be so evident. Therefore, our study contributes to the stakeholders' theory as it clearly shows that the stakeholders' needs are relevant for managers' disclosure decisions with regard to KPIs. The new regulatory framework introduced by the implementation of the EU Directive has led to an increase in KPI disclosures, but at the same time, due to its flexibility, it allows the companies to adjust their reporting to their stakeholders' needs. We believe that better alignment between the KPI internal use and external disclosure with taking into account stakeholder needs is crucial for the further development of non-financial reporting. It is also needed for the increased comparability of the disclosures between companies and a wider acceptance among accountants and assurance providers due to the numerical character of the data disclosed.

The practical contribution of the study stems from providing an incentive to the governmental agencies, national accounting associations, standard-setters and practitioners to improve the quality of KPI disclosures provided by the large PIEs operating in Poland and develop a holistic system of CSR measurement. We share the view expressed by LoulouBaklouti and Triki (2018), that bodies which set accounting standards could regulate nonfinancial information disclosure by developing relevant communication standards in 
accordance with stakeholders' expectations. They may identify information items that should be considered as a priority and make their disclosure mandatory. Our study shows that KPI disclosures on environment and society may trigger disclosures on employee matters. This information might be useful for the regulators who can concentrate on the KPIs related to the environment and society and expect subsequent disclosures on employee-related KPIs. Our findings may also be useful for corporate managers who build their non-financial disclosure strategies. Depending on the industry their company operates in, they should focus on the information needs of particular stakeholder groups. What is more, they should be aware of the influence of environmental and social disclosures for the reporting concerning employee matters.

The EC in the guidelines on reporting climate-related information on climate change proposes 14 KPIs in such categories as greenhouse gas emissions, energy, physical risk, products and services, green finance, along with a unit of measure, an example, rationale, alignment with other reporting frameworks and the EU policy reference (EC, 2019). The consultations on the review of the Directive 2014/95/EU which were launched in February and concluded in May 2020 might be a good moment to introduce a more harmonized approach to KPI disclosures. A number of questions in the survey concerned the evaluation of current standards and the introduction of a possible common European non-financial reporting standard. We propose that the EC might consider developing a set of social KPI indicators, following the approach taken with respect to those related to climate change and with taking into consideration the opinions of the companies' employees on which social KPIs are particularly relevant. Companies which fail to provide high quality environmental and social KPIs should also be under greater scrutiny, as it might have a negative impact on the employee-related KPIs they disclose.

Our study is not free from limitations. One of them is the sample size. It is limited, but at the same time, it covers all large PIEs required to provide KPI disclosures. The second is that we have focused on one country in our analysis. The use of the data for a country where the CSR concept is more developed and companies have longer experience in KPI disclosures might lead to different findings. Therefore, the replication of our research with more data from different countries could enable generalization and a meta-analytic combination of results of the studies. Furthermore, an interesting direction for future research would be to explore concrete situations regarding the possible influence of stakeholders on the design and evolution of the performance measurement system in the companies. The case studies could focus especially on the stakeholders' interactions with companies on the development of non-financial KPIs (use internally and externally). Moreover, it would be interesting to examine with interviews or surveys how/if any stakeholders may impact the choice of KPIs and the consequences of the development of these KPIs and to determine if their use effectively leads to the implementation of a better social strategy and practice.

\section{Notes}

1. The definition of PIEs was introduced by the Statutory Audit Directive (EU, 2006) and updated in 2014 (EU, 2014a). PIEs are entities governed by the law of an EU Member State whose transferable securities are admitted to trading on a regulated market of any Member State, credit institutions, insurance undertakings or entities designated by the Member States as publicinterest entities. PIEs examples are therefore public companies, banks or insurers Deloitte (2015). It should be noted that the Member States can differ in the way they consider entities to be PIEs.

2. For example, a retail company may use the sales per square metre and customer satisfaction ratio as a KPI, while an oil and gas company may opt for a KPI which would allow assessing 
MEDAR 29,7 progress in search of new oil fields. The decision which KPI to disclose will be driven by the industry-specific characteristics which, at the same time, are closely related to stakeholder information needs (PriceWaterhouseCoopers, 2007).

3. Non-financial information standard was developed by the Polish Association of Listed Companies with the cooperation of experts from the field of non-financial reporting, sustainability and CSR. It was published in October 2017 (SEG, 2020).

\section{References}

Adams, C.A., Hill, W. and Roberts, C.B. (1998), "Corporate social reporting practices in Western Europe: legitimating corporate behaviour?", The British Accounting Review, Vol. 30 No. 1, pp. 1-21, doi: 10.1006/bare.1997.0060.

Aldama, L.R.P., Amar, P.A. and Trostianki, D.W. (2009), "Embedding corporate responsibility through effective organizational structures", Corporate Governance, Vol. 9 No. 4, pp. 506-516, doi: $10.1108 / 14720700910985043$.

Andrades Peña, J. and Jorge, M. (2019), "Examining the amount of mandatory non-financial information disclosed by Spanish state-owned enterprises and its potential influential variables", Meditari Accountancy Research, Vol. 27 No. 4, pp. 534-555, doi: 10.1108/MEDAR-052018-0343.

Arvidsson, S. (2011), "Disclosure of non-financial information in the annual report: a managementteam perspective", Journal of Intellectual Capital, Vol. 12 No. 2, pp. 277-300, doi: 10.1108/ 14691931111123421.

Banerjee, S.B., Iyer, E.S. and Kashyap, R.K. (2003), "Corporate environmentalism: antecedents and influence of industry type", Journal of Marketing, Vol. 67 No. 2, pp. 106-122, doi: 10.1509/ jmkg.67.2.106.18604.

Beattie, V., McInnes, W. and Fearnley, S. (2004), "A methodology for analysing and evaluating narratives in annual reports: a comprehensive descriptive profile and metrics for disclosure quality attributes", Accounting Forum, Vol. 28 No. 3, pp. 205-236, doi: 10.1016/j. accfor.2004.07.001.

Beske, F., Haustein, E. and Lorson, P.C. (2020), "Materiality analysis in sustainability and integrated reports", Sustainability Accounting, Management and Policy Journal, Vol. 11 No. 1, pp. 162-186, doi: 10.1108/SAMPJ-12-2018-0343.

Bradford, M., Earp, J.B., Showalter, D.S. and Williams, P.F. (2017), "Corporate sustainability reporting and stakeholder concerns: is there a disconnect?", Accounting Horizons, Vol. 31 No. 1, pp. 83-102.

Bradley, O.J. and Botchway, G.O. (2018), "Communicating corporate social responsibility (CSR) in the coffee industry: an examination of indicators disclosed", sustainability accounting", Sustainability Accounting, Management and Policy Journal, Vol. 9 No. 2, pp. 139-164, doi: 10.1108/SAMPJ-02-20170015.

Brammer, S. and Pavelin, S. (2008), "Factors influencing the quality of corporate environmental disclosure", Business Strategy and the Environment, Vol. 17 No. 2, pp. 120-136, doi: 10.1002/ bse.506.

Branco, M.C. and Rodrigues, L.L. (2008), "Factors influencing social responsibility disclosure by Portuguese companies", Journal of Business Ethics, Vol. 83 No. 4, pp. 685-701, doi: 10.1007/ s10551-007-9658-z.

Burnett, R.D. and Hansen, D.R. (2008), "Ecoefficiency: defining a role for environmental cost management", Accounting, Organizations and Society, Vol. 33 No. 6, pp. 551-581, doi: 10.1016/j. aos.2007.06.002.

Buysse, K. and Verbeke, A. (2003), "Proactive environmental strategies: a stakeholder management perspective", Strategic Management Journal, Vol. 24 No. 5, pp. 453-470, doi: 10.1002/smj.299. 
Campbell, D., Moore, G. and Shrives, P. (2006), "Cross-Sectional effects in community disclosure", Accounting, Auditing and Accountability Journal, Vol. 19 No. 1, pp. 96-114, doi: 10.1108/ 09513570610651966.

Chang, K., Kim, I. and Li, Y. (2014), “,the heterogeneous impact of corporate social responsibility activities that target different stakeholders", Journal of Business Ethics, Vol. 125 No. 2, pp. 211-234, doi: 10.1007/s10551-013-1895-8.

Clarke, J. and Gibson-Sweet, M. (1999), "The use of corporate social disclosures in the management of reputation and legitimacy: a cross sectoral analysis of UK top 100 companies", Business Ethics: A European Review, Vol. 8 No. 1, pp. 5-13, doi: 10.1111/1467-8608.00120.

Collins, L. (2010), "Platform ploy", Engineering and Technology, Vol. 5 No. 18, pp. 60-63, doi: 10.1049/ et.2010.1816.

Coram, P.J., Mock, T.J. and Monroe, G.S. (2011), "Financial analysts' evaluation of enhanced disclosure of non-financial performance indicators", The British Accounting Review, Vol. 43 No. 2, pp. 87-101, doi: 10.1016/j.bar.2011.02.001.

Coy, D.V. (1995), “A public accountability index for annual reporting by NZ universities”, Unpublished $\mathrm{PhD}$ thesis, University of Waikato, Hamilton, New Zealand.

Cropanzano, R. and Rupp, D.E. (2008), "Social exchange theory and organizational justice: job performance, citizenship behaviors, multiple foci, and a historical integration of two literatures", in Gilliland, S.W., Steiner, D.D. and Skarlicki, D.P. (Eds), Emerging Perspectives on Managing Organizational Justice, Information Age Publishing, Greenwich, pp. 63-99.

Curtis, A., Lundholm, R. and McVay, S. (2014), "Forecasting sales: a model and some evidence from the retail industry", Contemporary Accounting Research, Vol. 31 No. 2, pp. 581-608, doi: 10.1111/ 1911-3846.12040.

Da Silva, S.M. and Aibar-Guzmán, B. (2010), "Determinants of environmental disclosure in the annual reports of large companies operating in Portugal", Corporate Social Responsibility and Environmental Management, Vol. 17 No. 4, pp. 185-204, doi: 10.1002/csr.197.

De Villiers, C. (2018), "Stakeholder requirements for sustainability reporting”, in De Villiers, C. and Maroun, W. (Eds), Sustainability Accounting and Integrated Reporting, Routledge, Abingdon, pp. 57-63.

De Villiers, C. and Van Staden, C. (2011), "Where firms choose to disclose voluntary environmental information", Journal of Accounting and Public Policy, Vol. 30 No. 6, pp. 504-525.

Deloitte (2012), "CFO insights: sustainability: developing key performance indicators. Measuring sustainability is the bottom line", available at: www2.deloitte.com/content/dam/Deloitte/cn/ Documents/finance/deloitte-cn-cfo-insights-sustainability-developing-key-performance-indicatorsen-201206.pdf (accessed 20 April 2020).

Deloitte (2015), "Public interest entity: definition and scope", available at: www2.deloitte.com/content/ dam/Deloitte/global/Documents/Audit/gx-audit-public-Interest-entity.pdf (accessed 9 July 2020).

Ditlev-Simonsen, C.D. and Wenstøp, F. (2013), "How stakeholders view stakeholders as CSR motivators", Social Responsibility Journal, Vol. 9 No. 1, pp. 137-147, doi: 10.1108/17471111311307868.

Driver, C. and Thompson, G. (2002), "Corporate governance and democracy: the stakeholder debate revisited", Journal of Management and Governance, Vol. 6 No. 2, pp. 111-130, doi: 10.1023/ A:1015721819591.

Dumay, J., La Torre, M. and Farneti, F. (2019), "Developing trust through stewardship: implications for intellectual capital, integrated reporting, and the EU directive 2014/95/EU", Journal of Intellectual Capital, Vol. 20 No. 1, pp. 11-39, doi: 10.1108/JIC-06-2018-0097.

EC (2017), "European commission. Guidelines on non-financial reporting (methodology for reporting non-financial information), C/2017/4234", available at: https://eur-lex.europa.eu/legal-content/ EN/TXT/?uri=CELEX:52017XC0705(01) (accessed 16 July 2020).

EC (2019), "European commission. Guidelines on reporting climate-related information. Guidelines on non-financial reporting: supplement on reporting climate-related information C/2019/4490", 
MEDAR 29,7

available at: https:/eur-lex.europa.eu/legal-content/EN/TXT/?uri=CELEX\%3A52019XC0620\% $2801 \% 29$ (accessed 16 June 2020).

Ellis, A.D. (2009)," "The impact of corporate social responsibility on employee attitudes and behaviours", Academy of Management Proceedings, Vol. 2009 No. 1, doi: 10.5465/ambpp.2009.44251836.

Ernst and Young (2015), “Tomorrow's investment rules 2.0", available at: www.ey.com/Publication/ vwLUAssets/EY-tomorrows-investment-rules-2/\$FILE/EY-tomorrows-investmentrules-2.0.pdf (accessed 15 April 2020).

EU (2006), "Directive 2006/43/EC of the European parliament and of the council of 17 may 2006 on statutory audits of annual accounts and consolidated accounts, amending council Directives78/ 660/EEC and 83/349/EEC and repealing council directive 84/253/EEC", available at: https://eurlex.europa.eu/legal-content/EN/TXT/?uri=CELEX\%3A32006L0043 (accessed 9 July 2020).

EU (2014a), "Directive 2014/56/EU of the European parliament and of the council of 16 April 2014 amending directive 2006/43/EC on statutory audits of annual accounts and consolidated accounts", available at: https://eur-lex.europa.eu/legal-content/EN/TXT/?uri=celex\%3A32014L0056 (accessed 10 July 2020).

EU (2014b), "Directive 2014/95/EU of the European parliament and of the council of 22 October 2014 amending directive 2013/34/EU as regards disclosure of non-financial and diversity information by certain large undertakings and groups", available at: https:/eur-lex.europa.eu/legal-content/ EN/TXT/HTML/?uri=CELEX:32014L0095\&from=EN (accessed 10 April 2020).

Farneti, F., Casonato, F., Montecalvo, M. and de Villiers, C. (2019), "The influence of integrated reporting and stakeholder information needs on the disclosure of social information in a stateowned enterprise", Meditari Accountancy Research, Vol. 27 No. 4, pp. 556-579, doi: 10.1108/ MEDAR-01-2019-0436.

Fassin, Y. (2012), "Stakeholder management, reciprocity and stakeholder responsibility", Journal of Business Ethics, Vol. 109 No. 1, pp. 83-96, doi: 10.1108/MEDAR-01-2019-0436.

Fernandez-Feijoo, B., Romero, S. and Ruiz, S. (2013), "Effect of stakeholders' pressure on transparency of sustainability reports within the GRI framework", Journal of Business Ethics, Vol. 122 No. 1, pp. 53-63, doi: 10.1007/s10551-013-1748-5.

Freeman, R.E. (1984), Strategic Management: A Stakeholder Approach, Pitman, Boston.

FSR (2020), "Raporty spólek [reports of companies]", available at: https://standardy.org.pl/raportyspolek (accessed 5 April 2019).

Gamerschlag, R., Möller, K. and Verbeeten, F. (2011), "Determinants of voluntary CSR disclosure: empirical evidence from Germany”, Review of Managerial Science, Vol. 5 Nos 2/3, pp. 233-262, doi: 10.1007/s11846-010-0052-3.

Gao, S. and Zhang, J. (2001), "A comparative study of stakeholder engagement approaches in social auditing", in Andriof, J. and McIntosh, M. (Eds), Perspectives on Corporate Citizenship, Greenleaf Publishing, Sheffield, pp. 239-255.

Garanina, T. and Dumay, J. (2017), "Forward-looking intellectual capital disclosure in IPOs", Journal of Intellectual Capital, Vol. 18 No. 1, pp. 128-148, doi: 10.1108/JIC-05-2016-0054.

Givoly, D., Li, Y., Lourie, B. and Nekrasov, A. (2019), "Key performance indicators as supplements to earnings: incremental informativeness, demand factors, measurement issues, and properties of their forecasts", Review of Accounting Studies, Vol. 24 No. 4, pp. 1147-1183, doi: 10.1007/s11142019-09514-y.

Gray, R., Adams, C. and Owen, D. (2017), "Social and environmental accounting”, in Roslender, R. (Ed.), The Routledge Companion to Critical Accounting, Routledge, New York, NY, pp. 243-259.

Gray, R.H., Kouhy, R. and Lavers, S. (1995), "Methodological themes: constructing a research database of social and environmental reporting by UK companies", Accounting, Auditing and Accountability Journal, Vol. 8 No. 2, pp. 78-101, doi: 10.1108/09513579510086812. 
Guthrie, J. and Abeysekera, I. (2006), "Content analysis of social, environmental reporting: what is new?", Journal of Human Resource Costing and Accounting, Vol. 10 No. 2, pp. 114-126, doi: 10.1108/14013380610703120.

Hair, J.F., Black, W.C., Babin, B.J. and Anderson, R.E. (2010), Multivariate Data Analysis: International Version, Pearson, NJ.

Haski-Leventhal, D. (2013), "Employee engagement in CSR: the case of payroll giving in Australia", Corporate Social Responsibility and Environmental Management, Vol. 20 No. 2, pp. 113-128, doi: $10.1002 /$ csr.1287.

Healy, P.M. and Palepu, K. (2001), "Information asymmetry, corporate disclosure and the capital markets: a review of the empirical disclosure literature", Journal of Accounting and Economics, Vol. 31 Nos 1/3, pp. 405-440, doi: 10.1016/S0165-4101(01)00018-0.

Henri, J.F. and Journeault, M. (2010), "Eco-control: the influence of management control systems on environmental and organizational performance", Accounting Organizations and Society, Vol. 35 No. 1, pp. 63-80, doi: 10.1016/j.aos.2009.02.001.

Ho, L.C.J. and Taylor, M.E. (2007), “An empirical analysis of triple bottom-line reporting and its determinants: evidence from the United States and Japan", Journal of International Financial Management and Accounting, Vol. 18 No. 2, pp. 123-150, doi: 10.1111/j.1467646X.2007.01010.x.

Hoffmann, E., Dietsche, C. and Hobelsberger, C. (2018), "Between mandatory and voluntary: nonfinancial reporting by German companies", Nachhaltigkeits Management Forum, Vol. 26 Nos 1/4, pp. 47-63, doi: 10.1007/s00550-018-0479-6.

Hooley, G., Cox, T., Fahy, J., Shipley, D., Beracs, J., Fonfara, K. and Snoj, B. (2000), "Market orientation in the transition economies of Central Europe: tests of the narver and slater market orientation scales", Journal of Business Research, Vol. 50 No. 3, pp. 273-285, doi: 10.1016/S0148-2963(99) 00105-8.

Huang, C. and Kung, F. (2010), "Drivers of environmental disclosure and stakeholder expectation: evidence from Taiwan", Journal of Business Ethics, Vol. 96 No. 3, pp. 435-451, doi: 10.1007/ s10551-010-0476-3.

Hummel, K., Schlick, C. and Fifka, M. (2017), "The role of sustainability performance and accounting assurors in sustainability assurance engagements", Journal of Business Ethics, Vol. 154 No. 3, pp. 733-757, doi: 10.1007/s10551-016-3410-5.

Jones, D.A., Willness, C.A. and Madey, A. (2014), "Why are job seekers attracted by corporate social performance? Experimental and field tests of three signal-based mechanisms", Academy of Management Journal, Vol. 57 No. 2, pp. 383-404, doi: 10.5465/amj.2011.0848.

Kaur, A. and Lodhia, S. (2018), "Stakeholder engagement in sustainability accounting and reporting: a study of Australian local council", Accounting, Auditing and Accountability Journal, Vol. 31 No. 1, pp. 338-368, doi: 10.1108/AAAJ-12-2014-1901.

Kent, P. and Chan, C. (2009), "Application of stakeholder theory to corporate environmental disclosures", Corporate Ownership and Control, Vol. 7 No. 1, pp. 399-414, doi: 10.22495/cocv7ilc3p6.

Kent, P. and Zunker, T. (2015), "A stakeholder analysis of employee disclosures in annual reports", Accounting and Finance, Vol. 57 No. 2, pp. 533-563, doi: 10.1111/acfi.12153.

KPMG (2016), “Assurance over key performance indicators (KPIs)", available at: https:/home.kpmg/ xx/en/home/insights/2016/06/assurance-over-key-performance-indicators.html (accessed 10 April 2020).

La Torre, M., Sabelfeld, S., Blomkvist, M., Tarquinio, L. and Dumay, J. (2018), "Harmonising nonfinancial reporting regulation in Europe: practical forces and projections for future research", Meditari Accountancy Research, Vol. 26 No. 4, pp. 598-562, doi: 10.1108/MEDAR-02-2018-0290.

Lev, B. (1992), “Information disclosure strategy”, California Management Review, Vol. 34 No. 4, pp. 9-32, doi: $10.2307 / 41166701$. 
MEDAR 29,7
Lisi, I.E. (2015), "Translating environmental motivations into performance: the role of environmental performance measurement systems", Management Accounting Research, Vol. 29, pp. 27-44, doi: 10.1016/j.mar.2015.06.001.

Lisi, I.E. (2018), "Determinants and performance effects of social performance measurement systems", Journal of Business Ethics, Vol. 152 No. 1, pp. 225-225, doi: 10.1007/s10551-016-3287-3.

Lombard, M., Snyder-Duch, J. and Bracken, C.C. (2002), "Content analysis in mass communication: assessment and reporting of intercoder reliability", Human Communication Research, Vol. 28 No. 4, pp. 587-604.

Loulou-Baklouti, S. and Triki, M. (2018), "Preparers' and users' perception of intellectual capital information usefulness: a Tunisian exploratory study", Journal of Intellectual Capital, Vol. 19 No. 3, pp. 617-643, doi: 10.1108/JIC-12-2016-0147.

Michelon, G., Pilonato, S. and Ricceri, F. (2014), "CSR reporting practices and the quality of disclosure: an empirical analysis", Critical Perspectives on Accounting, Vol. 33, pp. 59-78, doi: 10.1016/j. cpa.2014.10.003.

Miles, S., (2019), "Stakeholder theory and accounting”, in Jeffrey, S., Harrison, J.B., Barney, R., Freeman, E. and Phillips, R.A. (Eds), The Cambridge Handbook of Stakeholder Theory, Cambridge University Press, Cambridge, pp. 173-210, doi: 10.1017/9781108123495.

Ministry of Finance (2020), "Wykaz JZP [the list of PIEs]", available at: www.gov.pl/web/finanse/ wykaz-jzp-1 (accessed 5 April 2019).

Mishra, S. and Suar, D. (2010), "Do stakeholder management strategy and salience influence corporate social responsibility in Indian companies?”, Social Responsibility Journal, Vol. 6 No. 2, pp. 306-327, doi: $10.1108 / 17471111011051784$.

Mohamed, M.K., Allini, A., Ferri, L. and Zampella, A. (2019), "Investors' perception on the usefulness of management report disclosures: evidence from an emerging market", Meditari Accountancy Research, Vol. 27 No. 6, pp. 893-920, doi: 10.1108/MEDAR-11-2018-0393.

Mura, M., Longo, M., Micheli, P. and Bolzani, D. (2018), "The evolution of sustainability measurement research", International Journal of Management Reviews, Vol. 20 No. 3, pp. 661-695, doi: 10.1111/ ijmr.12179.

Nielsen, A.E. and Thomsen, C. (2007), "Reporting CSR: what and how to say it?", Corporate Communications: An International Journal, Vol. 12 No. 1, pp. 25-40, doi: 10.1108/13563280710723732.

Nielsen, C., Lund, M. and Thomsen, P. (2017), "Killing the balanced scorecard to improve internal disclosure", Journal of Intellectual Capital, Vol. 18 No. 1, pp. 45-62, doi: 10.1108/JIC-02-2016-0027.

Parmenter, D. (2015), Key Performance Indicators: developing, Implementing, and Using Winning KPIs, John Wiley and Sons, Inc., Hoboken, NJ.

Perego, P. and Hartmann, F. (2009), "Aligning performance measurement systems with strategy: the case of environmental strategy”, Abacus, Vol. 45 No. 4, pp. 397-428, doi: 10.1111/j.14676281.2009.00297.x.

Pérez, A., García de los Salmones, M. D M. and López, C. (2015), "Corporate reputation in the Spanish context: an interaction between reporting to stakeholders and industry", Journal of Business Ethics, Vol. 129 No. 3, pp. 733-746, doi: 10.1007/s10551-014-2199-3.

Prado-Lorenzo, J.M., Gallego-Alvarez, I. and Garcia-Sanchez, I.M. (2009), "Stakeholder engagement and corporate social responsibility reporting: the ownership structure effect", Corporate Social Responsibility and Environmental Management, Vol. 16 No. 2, pp. 94-107, doi: 10.1002/csr.189.

PriceWaterhouseCoopers (2007), "Guide to key performance indicators. Communicating the measures that matter", available at: www.pwc.com/gx/en/audit-services/corporate-reporting/assets/pdfs/ uk_kpi_guide.pdf (accessed 21 April 2020).

Raffournier, B. (2006), "The determinants of voluntary financial disclosure by Swiss listed companies”, European Accounting Review, Vol. 4 No. 2, pp. 261-280, doi: 10.1080/09638189500000016. 
Rinaldi, L., Unerman, J. and Tilt, C.A. (2014), "The role of stakeholder engagement and dialogue in the sustainability accounting and reporting process", in Bebbington, J., Unerman, J. and O'Dwyer, B. (Eds), Sustainability Accounting and Accountability, (2nd ed.), Routhledge, New York, NY, pp. 86-107.

Scott, E.M., Cocchi, D. and Gemmell, J.C. (2014), "Defining a fit for purpose statistically reliable sustainability indicator", Sustainability Accounting, Management and Policy Journal, Vol. 5 No. 3, pp. 262-267, doi: 10.1108/SAMPJ-04-2014-0024.

SEG (2020), "Standard informacji niefinansowych (SIN)", available at: https://seg.org.pl/p1/standardinformacji-niefinansowych-sin (accessed 5 April 2020).

Sharma, S. and Henriques, I. (2005), "Stakeholder influences on sustainability practices in the Canadian Forest products industry", Strategic Management Journal, Vol. 26 No. 2, pp. 159-180, doi: 10.1002/smj.439.

Snider, J., Hill, R. and Martin, D. (2003), "Corporate social responsibility in the 21st century: a view from the world's most successful firms", Journal of Business Ethics, Vol. 48 No. 2, pp. 175-187, doi: 10.1023/B:BUSI.0000004606.29523.db.

Sweeney, L. and Coughlan, J. (2008), "Do different industries report corporate social responsibility differently? An investigation through the lens of stakeholder theory", Journal of Marketing Communications, Vol. 14 No. 2, pp. 113-124, doi: 10.1080/13527260701856657.

Tagesson, T., Blank, V., Broberg, P. and Collin, S.O. (2009), "What explains the extent and content of social and environmental disclosures on corporate websites: a study of social and environmental reporting in Swedish listed corporations", Corporate Social Responsibility and Environmental Management, Vol. 16 No. 6, pp. 352-364, doi: 10.1002/csr.194.

Thomson, I. (2007), "Mapping the terrain of sustainability accounting", in Unerman, J., Bebbington, J. and O'Dwyer, B. (Eds), Sustainability Accounting and Accountability, Routledge, New York, NY, pp. 19-36.

Vurro, C. and Perrini, F. (2011), "Making the most of corporate social responsibility reporting: disclosure structure and its impact on performance", Corporate Governance: The International Journal of Business in Society, Vol. 11 No. 4, pp. 459-474, doi: 10.1108/14720701111159280.

Wei, Y., Egri, C.P. and Lin, C.Y. (2009), "Do corporate social responsibility practices make a difference in Eastern and Western contexts?", Academy of Management 2009 Annual Meeting: Green Management Matters, AOM 2009, doi: 10.5465/ambpp.2009.44257915.

Welbeck, E.E. (2017), "The influence of institutional environment on corporate responsibility disclosures in Ghana", Meditari Accountancy Research, Vol. 25 No. 2, pp. 216-240, doi: 10.1108/ MEDAR-11-2016-0092.

Williams, S.J. and Adams, C.A. (2013), "Moral accounting? Employee disclosures from a stakeholder accountability perspective", Accounting, Auditing and Accountability Journal, Vol. 26 No. 3, pp. 449-495, doi: 10.1108/09513571311311892.

Wood, D.J. (2010), "Measuring corporate social performance: a review", International Journal of Management Reviews, Vol. 12 No. 1, pp. 0-84, doi: 10.1111/j.1468-2370.2009.00274.x.

Wu, H.Y. (2012), "Constructing a strategy map for banking institutions with key performance indicators of the balanced scorecard", Evaluation and Program Planning, Vol. 35 No. 3, pp. 303-320, doi: 10.1016/j.evalprogplan.2011.11.009. 


\section{MEDAR}

29,7

\section{8}

\section{Area}

Business-related KPIs

Investments

Warranties and customers service

Working capital management

Suppliers relations

Sales/marketing/distribution

Clients care/satisfaction

Production

Quality

Products/services offered

Others

Environment-related KPIS Emissions

Water use

Wastewater

Materials and products

Energy use

Package and waste
Examples of identified KPIs

- capital expenditure to sales revenues

- total amount of expenditures on research and development by the reporting entity during the reporting period in absolute amount and in \% terms

- values of warranties to sales

- time of complaint processing

- inventory to cost of goods sold times 365

- receivables to sales times 365

- payables to purchases times 365

- number of local suppliers to total suppliers

- proportion of procurement spending of a reporting entity at local suppliers in \% terms and in absolute amount

- export and online sales to total sales

- number of shops

- market share

- number of new clients to total clients

$-\mathrm{NPS}$

- number of production sites

- material and energy expenses to total expenses

- number of product controls to total products sold

- number of hours of control

- number of units and services provided

- number of product improvements introduced to total products offered

- profit to number of employees

- amount of carbon dioxide produced

- the amount of emissions in relation to the unit of production or revenues

- total amount of ozone-depleting substances per net value added

- use of water in natural units

- use of water to the number of employees; use of water to units of production

- use of water to revenues

- wastewater in natural units

- wastewater to units of production

- wastewater to revenues

- total volume of water recycled and/or reused during the reporting period in absolute amount and in \% terms

- use of selected materials in natural units

- use of selected materials to the number of employees

- use of selected materials to units of production

- use of selected materials to revenues

- use of energy in natural units

- energy expenses to the revenues

- renewable energy consumption as percentage of total energy consumption in the reporting period

- quantity of hazardous and non-hazardous wastes produced in absolute terms, as well as proportion of hazardous waste treated, given total waste reported by the reporting entity in absolute amount, in \% terms and in terms of change
Table A1.

Examples of the identified KPIs 


\section{Area \\ Environmental investments,} malfunctions, penalties

Society-related KPIS

Charity and sponsoring

Volunteering

Social initiatives, grants, investments

Complaints and nuisances

Employees-related KPIs Accidents

Training

Employment

Salaries

Leaves

Employees' assessments

Corruption, ethics, mobbing, discrimination
Examples of identified KPIs

- change in the entity's waste generation per net value added in $\%$ terms, in terms of change and in absolute amount

- the number of penalties related to the environment

- value of penalties related to the environment

- total amount of money given for charity

- amount of money given for charity to the total revenue

- number of volunteers

- number of volunteering projects

- number of volunteering hours

- number of beneficiaries

- number of social initiatives

- number of complaints issued by the local communities

- number of administrative proceedings

- the number of lost time injuries multiplied by $1,000,000$ to the employee total hours worked

- number of days' inability to work related to accidents at work

- number of potentially accidental incidents

- number of new injury cases divided by total number of hours worked by workers

- incident rates

- average number of training hours per employee

- number of trained employees

- total number of sessions of training

- direct and indirect costs of training per employee per year

- employee rotation; the number of employees internally recruited

- the number of interns

- number of paid and unpaid internships

- average recruitment time; number of women in managerial positions to total number of employees in terms of headcount or FTE

- average salary; average gross salary of women to average gross salary of men in particular grade categories

- total costs of employee workforce (wages and benefits) divided by the total revenue in that reporting period

- the number of employees currently on maternity/parental/ paternity leaves

- percentage of women who gave up work within 12 months of returning to work after having a child

- number of employees' assessed

- number of assessments performed

- percentage of employees assessed

- number of reports of corruption, mobbing or discrimination cases

- number of non-ethical behaviour cases

- the percentage of employees who underwent anti-corruption training

- the number of complaints regarding human rights violations

- total monetary value of paid and payable corruption-related fines imposed by regulators and courts in the reporting period

- average number of hours of training in anti-corruption issues per employee per year (as total hours of training in anti-corruption issues per year divided by total employees) performance indicators

Key

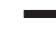


MEDAR

29,7

30

Trade unions and employee' benefits

Corporate boards

Area $\quad$ Examples of identified KPIs

- percentage of people from the local community in senior management positions at major business locations

- number of board meetings during the reporting period

- number of board members who participate at each board meeting during the reporting period divided by the total number of directors sitting on the board multiplied by the number of board meetings during the reporting period

- female board members to total board members

- number of board members by age range

- percentage of employees belonging to trade unions

- the total number of trade unions operating in the company

- number of strikes, the number of days lost due to strike

- number of employees covered by collective agreements to total employees (in terms of headcount or FTE)

\section{Table A1.}

\section{Corresponding author}

Joanna Krasodomska can be contacted at:joanna.krasodomska@uek.krakow.pl

For instructions on how to order reprints of this article, please visit our website: 